\title{
History of the Belanovica (Serbia) Neogene lake basin inferred from petrological and geochemical data
}

\author{
Dragana Marić*, ${ }^{*}$, Danica Srećković-Batoćanin ${ }^{2}$, Nebojša Vasić$^{2}$, Marija Radisavljević ${ }^{2}$ and \\ Tatjana Đekić ${ }^{1}$
}

${ }^{1}$ University of Niš, Faculty of Natural Sciences, Višegradska 33, 18000 Niš, Serbia; (dragana.maric@gmail.com)

2 University of Belgrade, Faculty of Mining and Geology, Đušina 7, 11000 Belgrade, Serbia

doi: 10.4154/gc.2019.05

(20)

Article history:

Manuscript received March 13, 2017

Revised manuscript accepted November 28, 2018

Available online Fabruary 15, 2019

\begin{abstract}
The petrological and geochemical composition of Neogene lacustrine successions and basement rocks of the Belanovica basin in Central Serbia, were investigated in three exploration boreholes, drilled in the central part of the former lake. Two boreholes accessed the basement, while the third one terminated in the lowermost Neogene interval, composed of coarse-grained clastics. Formation and diversification of the lake basin was influenced by strong syndepositional volcanic activity. The vertical distribution of selected elements from basal clastics $(\mathrm{Cr}, \mathrm{Ni}$, and $\mathrm{Mg}$ ) and from overlying lake sediments ( $\mathrm{Ba}, \mathrm{Sr}, \mathrm{Na}, \mathrm{K}$, etc.) indicates both the southern and northern margins of the basin, as potential source areas. The elemental concentrations are consistent with petrography. Based on the derived data, a reconstruction of the basin history is presented. The lack of index fossils resulted in a less accurate stratigraphy and the need for further updating by employment of the fission-track low-temperature thermochronometers. Additionally, outcrop studies and correlation with lake sediments in the Valjevo-Mionica basin is suggested.
\end{abstract}

VIĆ et al., 1997; OBRADOVIĆ \& VASIĆ, 2007; KRSTIĆ et al., 2012; NEUBAUER et al., 2016).

The manner of presentation of the Serbian lakes is also highly diverse. Lake basins were presented either according to their age and depressions where they have been developed (ANĐELKOVIĆ et al., 1991; OBRADOVIĆ \& VASIĆ, 2007) or were classified geographically, such as basins in northern, central and eastern Serbia (KRSTIĆ et al., 2003; DOLIĆ, 1986). According to KRSTIĆ et al. (2003) the lake basins are remnants of a single lake (Lake Serbia), whereas other authors recognized many Miocene lakes in mostly endemic and/or geographically isolated environments (e.g. MAROVIĆ et al., 2007; HARZHAUSER \& MANDIĆ, 2008). Furthermore, the geochemistry including isotope studies of the Serbian lakes is little known. The present study fills that gap by providing geochemical data that support results obtained by classic petrographic techniques. The objective in this study was to determine the range of concentrations of selected elements, which are indicative for the source of material: ultramafic rocks, or acid igneous, and metamorphic rocks.

\section{REGIONAL GEOLOGICAL SETTING}

The Belanovica basin is part of the E-W trending Valjevo-Mionica-Belanovica graben (MAROVIĆ et al., 2007). This two-part graben structure (Belanovica in the east and Valjevo-Mionica segment in the west) was one of the major depressions within the Peri-Pannonian Realm. Subsequent movements along the diagonal faults led to the separation of individual basins (ANĐELKOVIĆ et al., 1991). The more intensive subsidence along the southernborder fault and asymmetrical inversion revealed a markedly asymmetrical Belanovica basin (MAROVIĆ et al., 2007). The northern margin of the Belanovica basin is formed by the Brajkovac and Bukulja Mountains, composed of $\sim 30-20$ Ma old granitoid rocks (KNEŽEVIĆ et al., 1994; CVETKOVIĆ et al., 2007) and Devonian to Carboniferous low-grade metamorphic rocks 


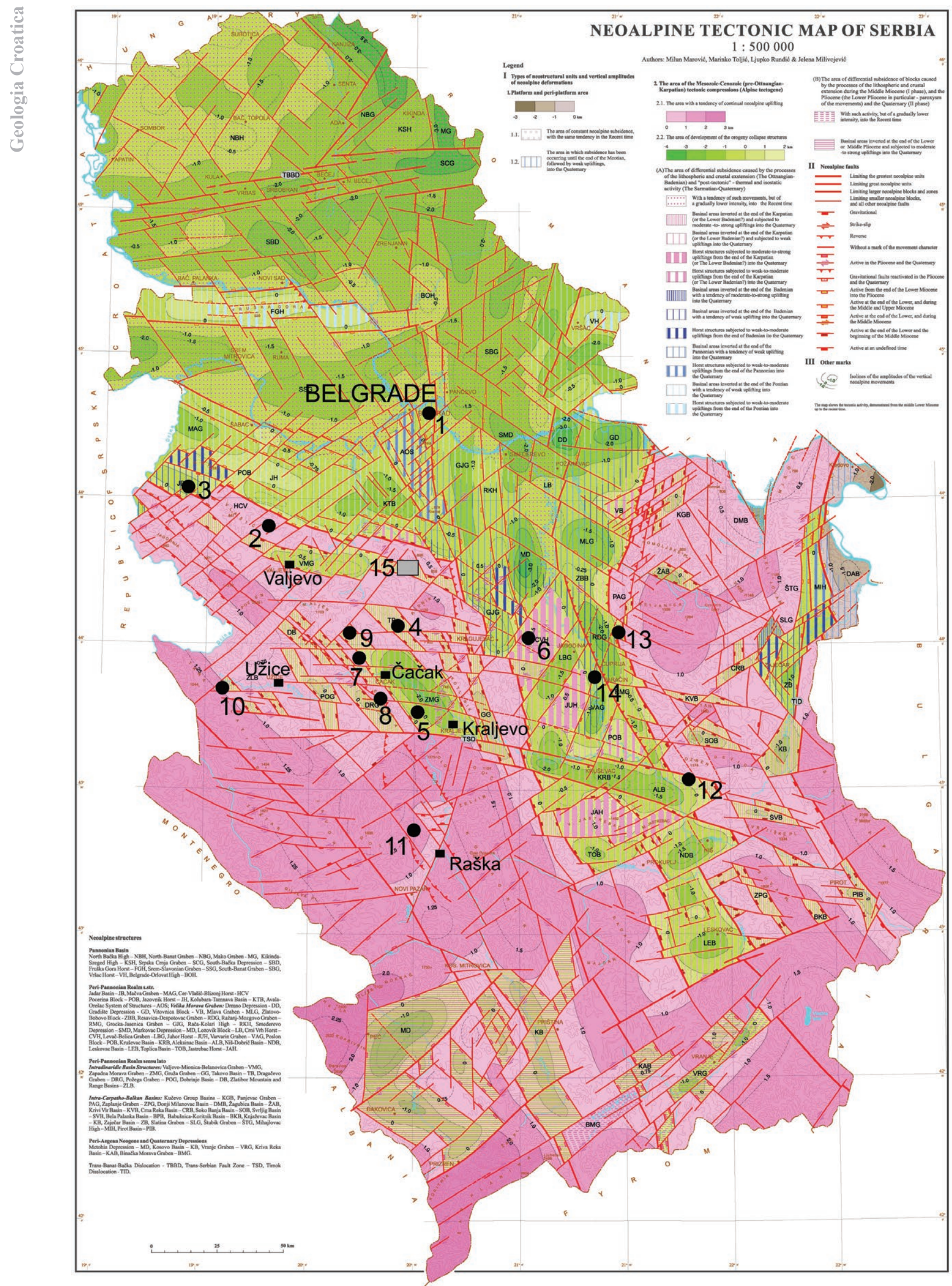

Figure 1. Neoalpine tectonic map of Serbia 1:500.000 (MAROVIĆ et al., 2007) with locations of the lacustrine basins (OBRADOVIĆ \& VASIĆ, 2007).

Legend: 1. Slanci (Slanci-Grocka) basin; 2. Valjevo-Mionica basin; 3. Jadar basin; 4. Takovo-Gomji Milanovac basin; 5. Čačak-Kraljevo basin; 6. Dobrinje-Ježevac basin; 7. Kosjerić basin; 8. Dragačevo basin; 9. Pranjani basin; 10. Kremna basin; 11. Kopaonik basin and Jarandol basin; 12. Aleksinac basin; 13. Senje-Resava basin, 14. Velika Morava trough (Niš, Zaplanje, Jelašnica, Leskovac, Barbeš, Ražanj, Popovac, Braničevo and Mlava basin) and 15. The position of Figure 2 is represented by the rectangle. 


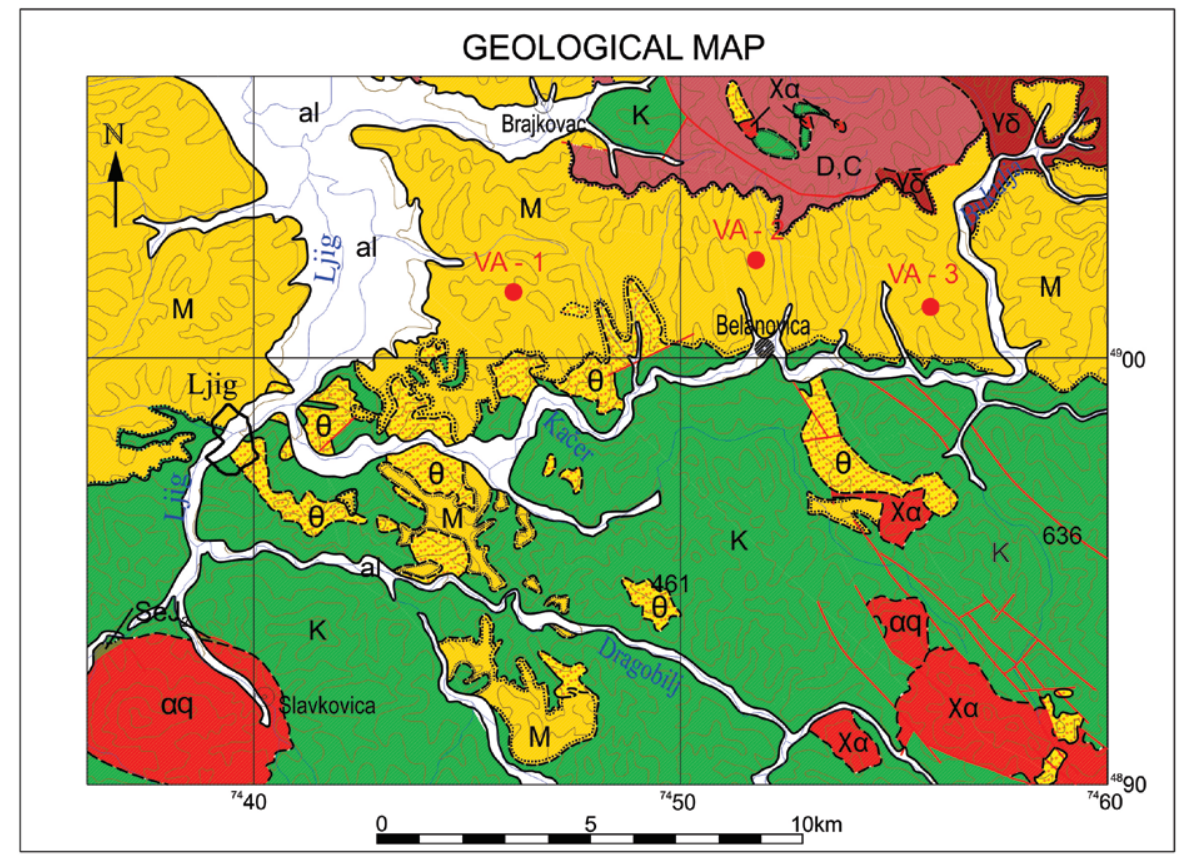

Legend

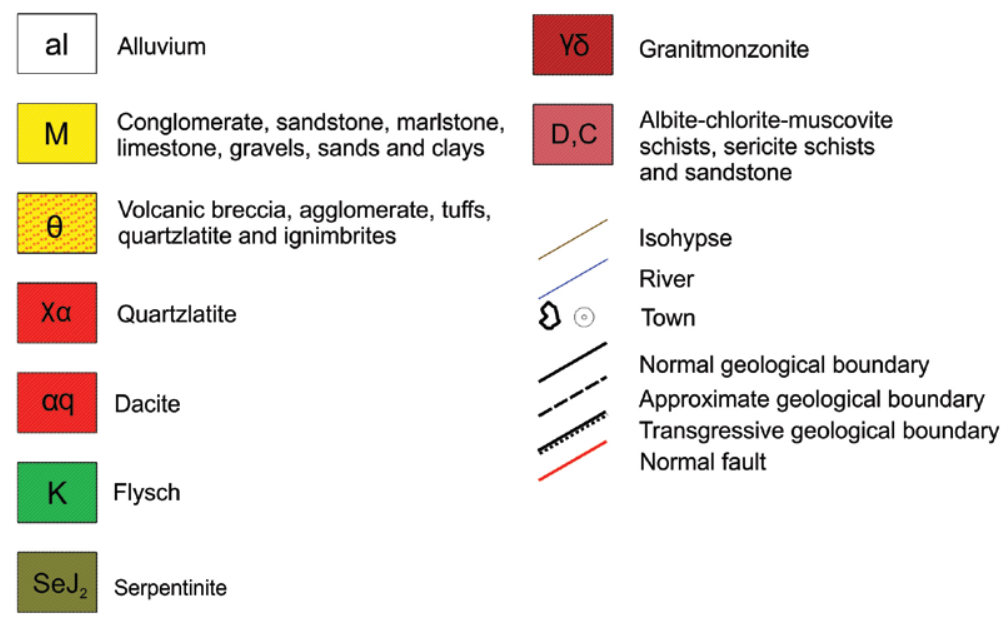

Figure 2. Geological map of the broader area of the Belanovica basin with borehole locations - detail from the Basic Geological Map 1:100.000, sheet Gornji Milanovac (FILIPOVIĆ et al., 1971). Redrawn by M. RADISAVLJEVIĆ, using AutoCad 2014 software.

(TRIVIĆ et al., 2010; MAROVIĆ et al., 2007). Its southern margin comprises Jurassic ophiolites dominated by serpentinite, Cretaceous flysch sediments and Miocene volcanic and volcaniclastic rocks (Fig. 2).

According to MAROVIĆ et al. (1999) the studied basin is included in the Serbian depositional province, which has been formed as a consequence of the Early Miocene extension and subsidence of the Pannonian basin due to Early-Middle Miocene collapse and core exhumation in the Sava zone and Tiszia (e.g. HORVATH et al., 2015). Extension of the Pannonian basin additionally increased the heat transfer that is presently still observed (MATENCO \& RADIVOJEVIC, 2012).

\section{MATERIALS AND METHODS}

All sedimentary rock samples were optically analyzed using a petrographic polarized microscope for transmitted light (Leica DMLSP), connected to a Leica DFC290 HD camera over the ap- plication LAS V4.1. Major and trace chemical elements (including REEs) contents were determined in 158 samples (76 from the borehole VA-1, 54 from VA-2 and 28 from VA-3) in the SGS laboratory in Lakefield (Canada) using ICP-AES analysis (ICP 12B package), with samples repeated to ensure analytical consistency. Samples were cleaned of weathered surfaces and crushed to $<2 \mathrm{~cm}$ before being ground to a $<200 \mu \mathrm{m}$ in an agate mill RETSCH PM 200. Accuracy and precision were estimated on the basis of standard rock materials and replicate analyses. Contents for 12 elements used in discussion in all 158 samples and detection limits are given in Supplementary Table. Procedures for manipulating data and drawing graphs were performed using Sigma Plot version 11.0 from SYSTAT Software Inc. San Jose, CA, USA; available at: www.systatsoftware.com.

Granulometry was determined in epiclastic and sandy-gravelly loose sediments. The amount of sample for analyses depends on the grain size, thus about $100 \mathrm{~g}$ was taken from the former and 
VA - 1

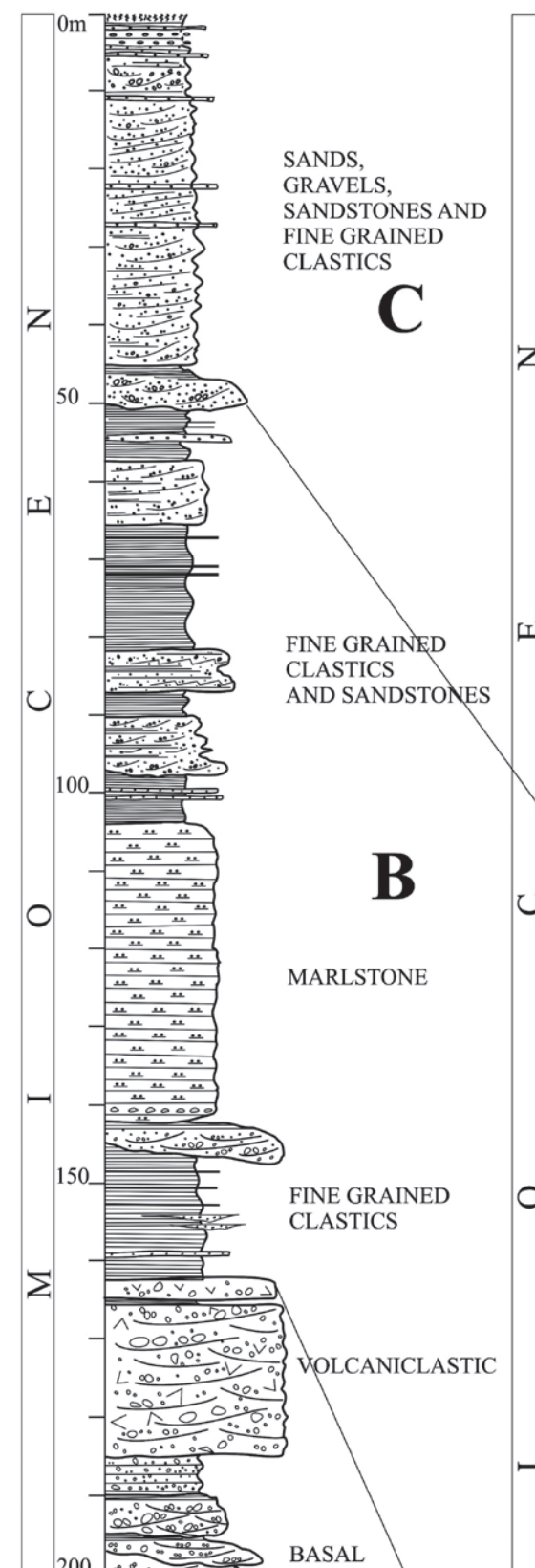

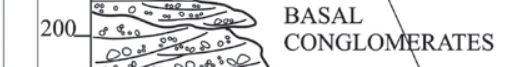

VA - 2

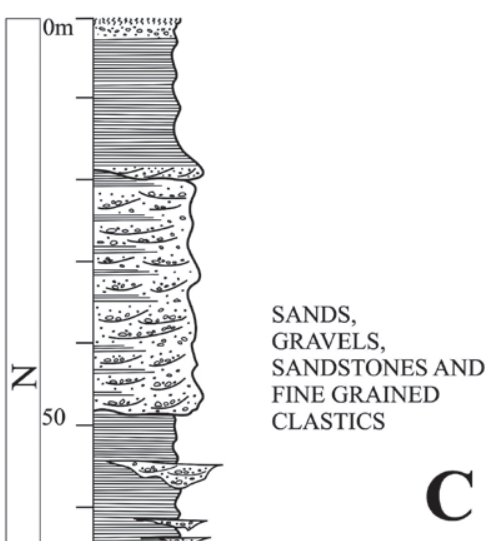

II)
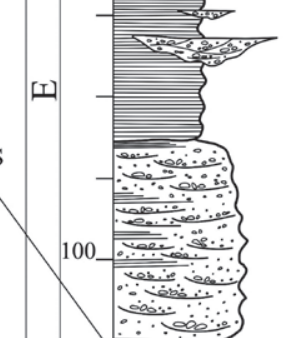

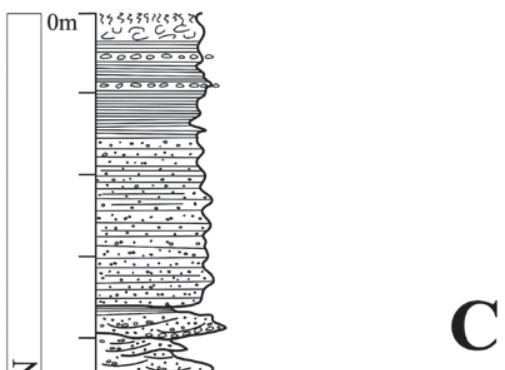

SANDS,

GRAVELS,

SANDSTONES AND

FINE GRAINED

CLASTICS

ALTERNATED

GRAVELS

SANDS AND

FINE GRAINED

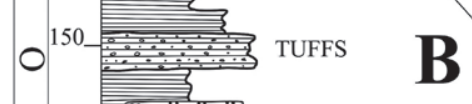

B CLASTICS

FINE GRAINED

CLASTCS WITH

THIN INTERLAYERS MARLSTONE
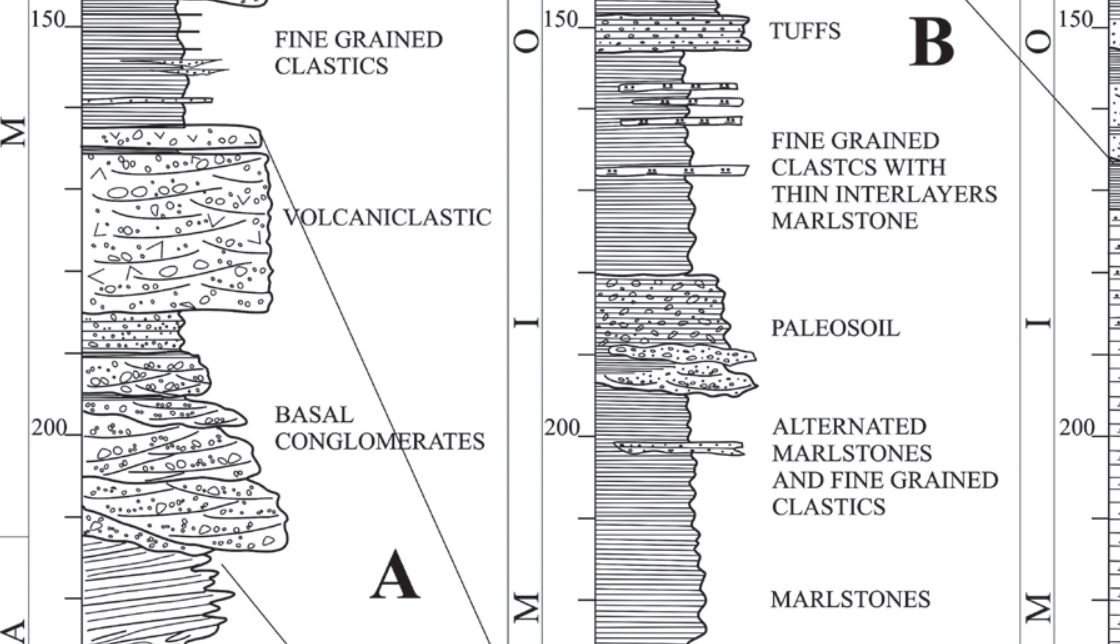

$\varangle$
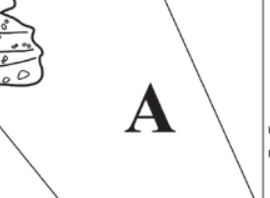

200

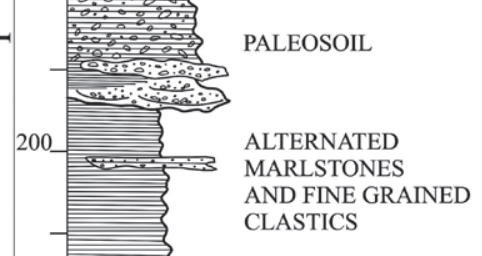

PALEOSOIL
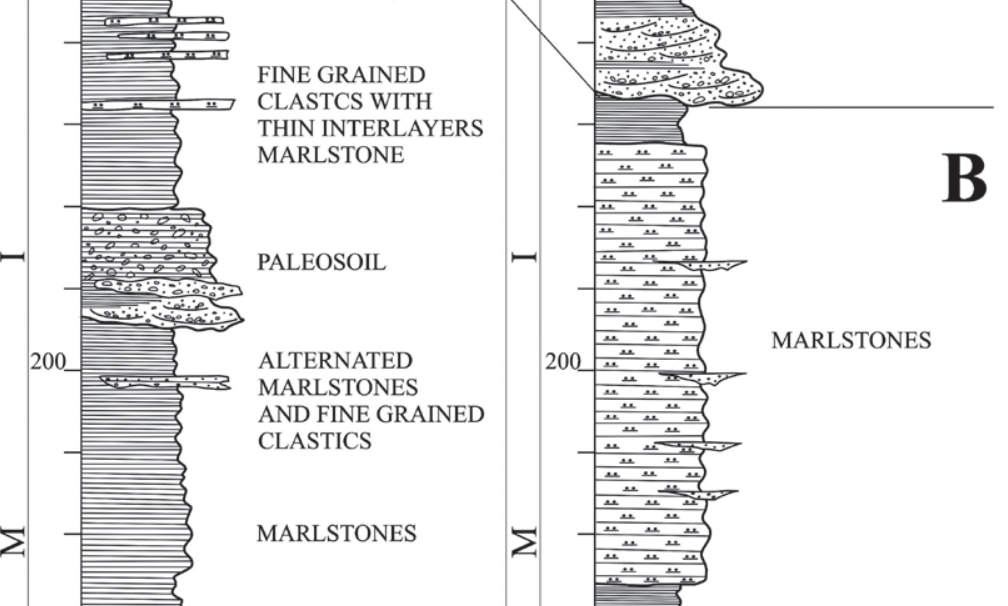

MARLSTONES

B

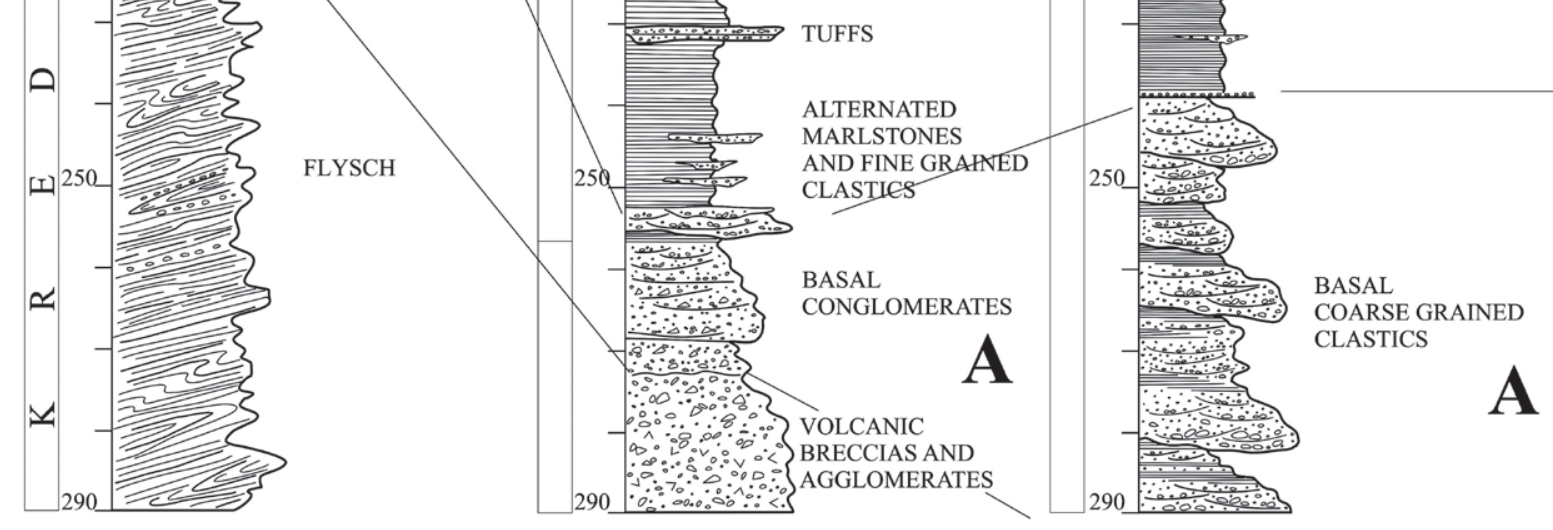

Figure 3. Lithostratigraphic columns of boreholes. Lithofacies are marked as in the text. Solid lines connect the same levels. 
Table 1. Modal analyses of redeposited volcaniclastic (epiclastic) rocks and sands from borehole VA-1. Average values and standard deviation were calculated for each constituent in both rock types. The depth of samples in metres is given in brackets.

\begin{tabular}{|c|c|c|c|c|c|c|c|c|c|c|c|c|c|}
\hline \multirow{2}{*}{ minerals in \% } & \multicolumn{5}{|c|}{ epiclastite } & \multicolumn{8}{|c|}{ sands } \\
\hline & 71 (188.5) & 67 (184.5) & 61 (171.3) & $60(167.0)$ & avg. \pm S.D. & $5(13.7)$ & $11(33.6)$ & $17(50.6)$ & $23(63.6)$ & $26(68.8)$ & $32(86.2)$ & 35 (96.5) & avg. \pm S.D. \\
\hline quartz & 86 & 40 & 45 & 48 & $55 \pm 18$ & 63 & 66 & 64 & 66 & 59 & 40 & 57 & $59 \pm 9$ \\
\hline feldspar & 6 & 30 & 9 & 7 & $13 \pm 10$ & 14 & 14 & 13 & 12 & 14 & 11 & 13 & $13 \pm 1$ \\
\hline rock fragm. & 8 & 30 & 45 & 44 & $32 \pm 15$ & 18 & 18 & 21 & 19 & 17 & 16 & 21 & $19 \pm 2$ \\
\hline calcite & tr. & tr. & tr. & tr. & - & 4 & 1 & 2 & 2 & 2 & 2 & 3 & $2 \pm 1$ \\
\hline muscovite & - & - & - & - & - & 1 & 1 & - & 1 & 5 & 15 & 4 & $4 \pm 5$ \\
\hline biotite & - & - & 1 & 1 & $0.5 \pm 0.5$ & - & - & tr. & tr. & tr. & tr. & tr. & - \\
\hline chlorite & tr. & - & - & - & - & - & - & - & - & 2 & 16 & 2 & $2 \pm 6$ \\
\hline faunal fragm. & tr. & tr. & - & tr. & - & tr. & - & - & tr. & 1 & tr. & tr. & - \\
\hline heavy min. & - & tr. & tr. & - & - & tr. & tr. & tr. & tr. & tr. & tr. & tr. & - \\
\hline
\end{tabular}

avg. - average; S.D. -Standard deviations; tr. -trace; - not detected.

up to $50 \mathrm{~g}$ from the finer-grained sediments. The qualitative-quantitative mineralogical composition was determined for four samples of epiclastites using the $>0.063 \mathrm{~mm}$ fractions, and in seven sand samples using fractions $0.125-0.25$ and $0.25-0.50 \mathrm{~mm}$. The highest dispersion of data is noted for quartz and rock fragment abundance in epiclastites. Average values and standard deviation are presented for each constituent in Table 1. Fractions were prepared by wet-sieving techniques and analyzed afterwards under the binocular microscope (Leica EZ4D) and a polarised light microscope (Leica DMLSP). The latter analysis required thin-sections prepared with xilol as the immersion liquid.

Micropalaeontological analyses included 36 samples washed and sieved under warm water (meshes $0.6-0.125 \mathrm{~mm}$ ); discrete details of fossil molds required additional cleaning using $6 \%$ hydrogen peroxide. Samples were analyzed by binocular microscope Leica (up to $35 \mathrm{x}$ magnification) and by reflected light microscope Olympus BH2 (magnification up to $100 \mathrm{x}$ ). Analyses were performed by RUNDIĆ at the Department for Palaeontology of the Faculty of Mining and Geology, University of Belgrade.

The content of $\mathrm{CaCO}_{3}$, as a proxy for carbonate content and precise determination of fine-grained clastites, was determined in 69 samples using a method of calcimetry and Scheibler's calcimeter. Depending on the intensity of the sample reaction with diluted $\mathrm{HCl}, 0.5 \mathrm{~g}$ or $1 \mathrm{~g}$ of sample was ground in an agate vial. All analyses were performed at the Department for Mineralogy, Crystallography, Petrology and Geochemistry of the Faculty of Mining and Geology, University of Belgrade.

\section{RESULTS}

Detailed mapping of cores from three exploration boreholes (VA-1, VA-2 and VA-3) enabled determination of the basin infill and basement rocks (Fig. 3). Neogene sediments in the borehole VA-1 overlie Cretaceous flysch (212-335 m) and volcanic and volcaniclastic rocks in VA-2 (268-296 m). The borehole VA-3 did not access the basement.

\section{Basement}

Weakly lithified, moderate to well-sorted sandstones prevail in flysch clastites in VA-1. Sandstones are stratified in thin to moderately thick beds and consist of rock fragments that were derived from metamorphic rocks (including serpentinites) and limestones. Flysch sediments in VA-1 containing serpentinite/ultramafite fragments have a high heavy metal content, particularly Ni (from 413 to $1429 \mathrm{ppm}$ ) and Cr (from 106 to $992 \mathrm{ppm}$; Supplementary Table).

Volcanic and volcaniclastic rocks (ignimbrites) in borehole VA-2 are products of volcanic activity dated to about $23 \mathrm{Ma}$ or younger (CVETKOVIĆ et al., 2000). Among them, the quartz latites of hypocrystalline porphyritic texture, followed by fragments of lamprophyres, were the most abundant products originating from Rudnik mountain (Fig. 4a). Heavy metal contents in the underlying rocks in VA-2 range from 9.4-10.6 ppm (Cr) and 4.4-5.2 ppm (Ni).

\section{Unit A}

The oldest Neogene unit is the "Basal coarse-grained clastites" (BCC; A in Fig. 3). They consist of material derived from the volcanic complex and flysch, from Triassic limestones or re-deposited volcaniclastic material (interval 212-162.5 $\mathrm{m}$ in VA-1; 268 to $258 \mathrm{~m}$ in VA-2 and 240-300 $\mathrm{m}$ in VA-3). Volcaniclastic material mostly consists of quartz $(38.3-86.1 \%)$ and rock fragments (7.7-45.0 \%). Feldspar is subordinate (2.7-4.8\%; Table 1). Fossil remains are lacking.

\section{Unit B}

The transition from BCC into the overlying unit (B in Fig. 3), "Marlstone and fine-grained clastites", marks the package of laminated and clayey siltstones (at $165 \mathrm{~m}$ depth in VA-1, and above $254 \mathrm{~m}$ depth in VA-2) where the lacustrine mollusc fauna occurs for the first time in the succession (remains of freshwater gastropods - $G y$ raulus sp., Planorbarius sp., Theodoxus sp.; Fig. 4b). The amount of sand and gravel in this unit increases laterally along with the thickness of the unit itself (from $110 \mathrm{~m}$ in VA-1 to $140 \mathrm{~m}$ in VA-2).

The given unit is typically represented in borehole VA-1 where three lithofacies are distinguished: (1) fine-grained clastites (sandy-clayey siltstones prevail); (2) marlstone (compositionally uniform) and (3) fine-grained clastites and sands. Horizontal lamination in lithofacies 1 . and 2., determined by laminae of different granulometry, colour, composition and thickness is common. Bioturbation occurs locally.

The aforementioned lithofacies are weakly differentiated in borehole VA-2, particularly when composed of marlstone. Sands composed of well-rounded grains originating from volcanic complex and flysch sediments occur throughout the column of VA-2, either as beds or as packages. The most abundant constituents of the sands are quartz (40.3-66.1\%; Table 1) and rock fragments (15.6-21.3\%). Feldspar occurs in significant amounts (10.6-14.1\%), as well as muscovite $(0.5-15.3 \%)$ and chlorite (1.6-15.7\%). Finegrained clastites of different shades of brick-red colour, as well as green silty clays with carbonate nodules within the interval 195-180 m (see Fig. 3) suggest subaerial exposure.

Unit B in column VA-3 displays an upward decrease in grainsize and thickness. Rounded pebbles in gravels were derived from clastites and altered volcanic rocks, while the finer-grained clas- 

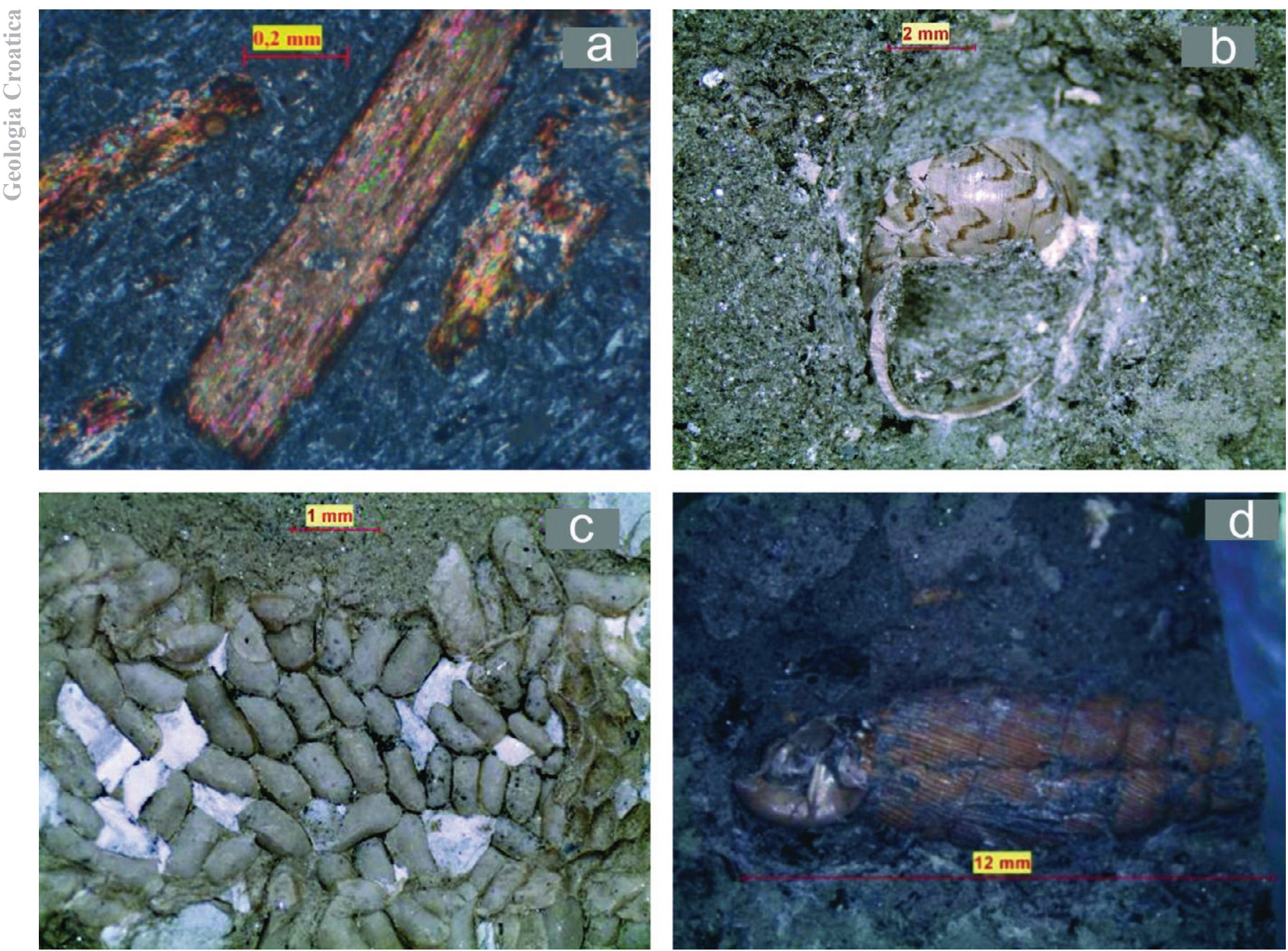

Figure 4. a.Photomicrograph of lamprophyre; b. Theodoxus sp.; c. Accumulated ostracods in marlstone at 195 m (VA-3); d. Clausilia sp.

tites are composed of fragments of metamorphic rocks. Sands display sedimentary structures of wave action (lenticular, wavy and flaser lamination). Debris of mollusc remains (molds) is common. Fine-grained clastites are calcite-clayey siltstones with $10-15 \%$ $\mathrm{CaCO}_{3}$ (Table 2). Deformational structures resulted from vertical and horizontal movements - small syn-sedimentary landslides. Fresh-water organisms were identified in marlstones: carbonized flora, fish bones and scales, pyritized shell valves, ostracods (Candona sp., Amplocypris sp., Hungarocypris? sp.) and gastropods. Accumulated, i.e. gathered ostracods are common (Fig. 4c).

\section{Unit C}

The youngest recognized unit (C in Fig. 3) is "Sand, gravel, sandstone and fine-grained clastites". Its boundary with the previous unit is marked by basal conglomerates.

A typical succession occurs within the VA-1, from the surface to $50 \mathrm{~m}$ depth. Sands are composed of quartz (63.2-66.1\%), rock fragments (18-21.1\%) and feldspars (12.8-14.0\%). Muscovite is less abundant (up to $1 \%$ ) and chlorite and biotite are lacking (first three samples of Table 1). Sands in the deeper sections are of different granulometry and colour, and are organized in sets of trough cross or cross and horizontal lamination. Elements of wave-action, such as wavy (ripple) lamination and weakly developed small-scale flaser or lenticular lamination, occur occasionally. In the upper part, thin to moderately thick beds of sandstone occur. Intraformational fragments of sandstone, originating from a basal unit ( $\mathrm{B}$ - marlstone and fine-grained clastites) reflects that the former sands were cemented by calcite. Sandstones are considered to represent sub-litharenite, litharenite and arkose having similar composition to the underlying exposed sands (Table 1).

Sand and gravel in VA-2 alternate with fine-grained clastites. Fine-grained clastites and marlstone display horizontal lamination. The content of freshwater bivalves (Mytilopsis sp. and $\mathrm{Pi}$ sidium $\mathrm{sp}$.), gastropods (Melanopsis $\mathrm{cf}$. decollata STOLICZKA, Melanopsis ex gr. lyrata NEUMAYR, Gyraulus ex gr. pulici BRUSINA, Prososthenia sp., Planorbarius sp.) and ostracods (Hungarocypris sp. and Candona sp.) is high.

Sands and gravels also comprise this unit in the VA-3 column too. Their boundary with the previous unit marks the sequence of yellowish-red coarse-grained gravels. Variations in shades of red, yellow and grey colours through the overall unit reflect on relatively shallow, oxygen-rich environment. The lower part of the unit includes alluvial-lacustrine sequences (polymict gravels) with a notable presence of fragments from metamorphic rocks. Sands vary in grain-size and display either horizontal or cross lamination. In finer-grained clastites, i.e. siltstones with more or less sandy fraction, one palaeosol horizon with two levels of carbonate concretions was detected. Their structures reflect waveaction (wavy lamination and weakly developed flaser or even lenticular lamination). Fossil material includes mollusc molds and well preserved terrestrial gastropods (e.g. Clausilia sp.; Fig. 4d). 


\section{DISCUSSION}

The natural concentration of elements in sediments is a function of the mineralogy of the source, the grain size and diagenetic processes/environment (MOURA \& KROONENBERG, 1990; HAKSTEGE et al., 1993; HUISMAN \& KIDEN, 1997). Sedimentary rocks derived near sources may inherit the source rock signatures, particularly the fine-grained ones due to their less variable composition in comparison with sandstones (CULLERS, 2000). These signatures may be later modified by weathering, hydraulic sorting and diagenesis (CULLERS et al, 1987). The obtained geochemical data for all the exposed rocks support the results from the common petrographic techniques and indicate the source rocks.

\section{Basement rocks}

Flysch in VA-1 contains rock fragments that were derived from metamorphic rocks (including serpentinites) and limestones. Their high Ni (413-1429 ppm) and Cr (106-992 ppm; Supplementary Table) contents reflect the southwestern part of the studied area with serpentinite as the predominant source material. In terms of sedimentology, flysch corresponds to the distal parts of the fan in the bottom of the basin. Considering the flysch sediments that outcrop about $15 \mathrm{~km}$ west of Belanovica (e.g. around the volcanic mass of Slavkovica) an Albian-Cenomanian age may be inferred. The presence of the brachiopod Kingena concinna OWEN in the coarse-grained clastites with serpentinite fragments suggests a Middle Cenomanian age, whereas the limestone fragments originate from the Upper Albian and Lower Cenomanian carbonates (RABRENOVIĆ et al., 2002; VASIĆ et al.,
2001). Volcanic and volcaniclastic rocks (ignimbrites) in borehole VA-2 are products of volcanism the evolution of which involves the mixing of ultrapotassic and calc-alkaline magmas, which has been very important and led to highly diverse products (CVETKOVIĆ et al., 2007; CVETKOVIĆ et al., 2001; PRELEVIĆ et al., 2001; PRELEVIĆ et al., 2004).

The contents of $\mathrm{Cr}(9.4-10.6 \mathrm{ppm})$ and $\mathrm{Ni}(4.4 .-5.2 \mathrm{ppm})$ in VA-2 are notably lower than in VA-1 (Supplementary Table). The average crustal abundance of $\mathrm{Ni}$ is $0.01 \%$, while in sedimentary rocks it ranges from 5-90 $\mu \mathrm{g} / \mathrm{g}$ (COX, 1995). The borehole VA-3 did not access the basement but considering the data from the Basic Geological Map corresponds to flysch sediments at the southern and to Devonian-Carboniferous metamorphic rocks at its northern margin (FILIPOVIĆ et al., 1971).

Basement rocks display lithological and geochemical differences indicating petrological and stratigraphic differences of palaeorelief at the onset of lake formation. According to the depth distribution of the Neogene basement the lake bottom was probably tilted towards the east, i.e. from VA-1 to VA-3.

\section{Basin infill (Neogene units) \\ Unit A (alluvial phase)}

The oldest Neogene unit is basal coarse-grained clastites (BCC). As deposition took place during a partly developed lake basin the character of an alluvial system remained, particularly in VA-3. $\mathrm{BCC}$ in VA-1 and VA-2 reflect the periodically high terrigenous input into the basin, most probably by torrential flows. It is composed of material derived from the volcanic complex and flysch, from Triassic limestones or re-deposited volcaniclastic material.

Table 2. The $\mathrm{CaCO}_{3} \%$ content in samples (for the long core samples, several powdered samples were made for analyses. Such samples have the same number but are signed by uppercase letters, e.g. $13 \mathrm{~A}, 13 \mathrm{~B}$, etc.).

\begin{tabular}{|c|c|c|c|c|c|c|c|c|c|c|c|c|c|c|}
\hline \multicolumn{5}{|c|}{ VA-1 } & \multicolumn{5}{|c|}{ VA-2 } & \multicolumn{5}{|c|}{ VA-3 } \\
\hline No. & sample & depth & $\% \mathrm{CaCO}_{3}$ & $\begin{array}{l}\text { rock determination after } \\
\text { FOLK et al. (1970) }\end{array}$ & No. & sample & depth & $\% \mathrm{CaCO}_{3}$ & $\begin{array}{l}\text { rock determination after } \\
3 \text { FOLK et al. (1970) }\end{array}$ & No. & sample & depth & $\% \mathrm{CaCO}_{3}$ & $\begin{array}{l}\text { rock determination after } \\
{ }^{3} \text { FOLK et al. (1970) }\end{array}$ \\
\hline 1 & 15 & 45.3 & 7.6 & sandy-clayey siltstone & 32 & 13 & 241.3 & 22.1 & calcite-clayey siltstone & 49 & 10 & 241.7 & 10.2 & calcite-clayey siltstone \\
\hline 2 & 18 & 52.2 & 44.2 & marlstone & 33 & 14 & 243.3 & 11.9 & calcite-clayey siltstone & 50 & $13 \mathrm{~A}$ & 224.5 & 20.4 & calcite-clayey siltstone \\
\hline 3 & 19 & 54.0 & 10.2 & calcite-clayey siltstone & 34 & 17 & 222.7 & 39.9 & marlstone & 50 & $13 B$ & 219.4 & 35.7 & marlstone \\
\hline 4 & 20 & 55.6 & 10.2 & calcite-clayey siltstone & 35 & 18 & 214.8 & 25.5 & calcite-clayey siltstone & 50 & $13 C$ & 211.1 & 34.8 & marlstone \\
\hline 5 & 21 & 59.1 & 12.7 & calcite-clayey siltstone & 36 & 19 & 201.7 & 42.5 & marlstone & 50 & $13 \mathrm{D}$ & 204.3 & 37.4 & marlstone \\
\hline 6 & 25 & 67.7 & 13.6 & calcite-clayey siltstone & 37 & 20 & 195.3 & 7.6 & clayey- sandy siltstone & 50 & $13 \mathrm{E}$ & 203.6 & 41.6 & marlstone \\
\hline 7 & 27 & 70.8 & 16.1 & calcite-clayey siltstone & 38 & 25 & 160.4 & 11.9 & calcite-clayey siltstone & 50 & $13 \mathrm{~F}$ & 195.0 & 21.2 & calcite-clayey siltstone \\
\hline 8 & 29 & 75.4 & 13.6 & calcite-clayey siltstone & 39 & 26 & 158.7 & 54.4 & marlstone & 50 & $13 G$ & 186.5 & 39.9 & marlstone \\
\hline 9 & 30 & 79.9 & 17.0 & calcite-clayey siltstone & 40 & 28 & 140.7 & 16.1 & calcite-clayey siltstone & 50 & 131 & 182.0 & 27.2 & calcite-clayey siltstone \\
\hline 10 & 33 & 88.2 & 12.7 & calcite-clayey siltstone & 41 & $30 C$ & 130.2 & 10.2 & calcite-clayey siltstone & 50 & $13 \mathrm{H}$ & 181.0 & 38.2 & marlstone \\
\hline 11 & 36 & 99.5 & 14.4 & calcite-clayey siltstone & 41 & $30 \mathrm{~B}$ & 128.0 & 11.9 & calcite-clayey siltstone & 50 & 13J & 177.6 & 31.4 & calcite-clayey siltstone \\
\hline 12 & 37 & 103.4 & 17.0 & calcite-clayey siltstone & 41 & $30 \mathrm{~A}$ & 127.1 & 48.4 & marlstone & 50 & $13 \mathrm{~K}$ & 173.0 & 28.0 & calcite-clayey siltstone \\
\hline 13 & 38 & 105.7 & 50.1 & marlstone & 42 & 33 & 110.5 & 17.0 & calcite-clayey siltstone & 51 & 14 & 168.2 & 13.6 & calcite-clayey siltstone \\
\hline 15 & 40 & 11.4 & 27.2 & calcite-clayey siltstone & 44 & $36 C$ & 84.0 & 43.3 & marlstone & 53 & 21 & 98.2 & 12.7 & calcite-clayey siltstone \\
\hline 16 & 41 & 113.7 & 56.9 & marlstone & 44 & $36 B$ & 79.2 & 34.0 & calcite-clayey siltstone & 54 & 26 & 48.9 & 4.2 & clayey siltstone \\
\hline 17 & 42 & 117.5 & 39.9 & marlstone & 44 & $36 \mathrm{~A}$ & 78.5 & 28.9 & calcite-clayey siltstone & 55 & 29 & 11.1 & 11.0 & calcite-clayey siltstone \\
\hline 18 & 43 & 121.3 & 46.7. & marlstone & 45 & 38 & 66.6 & 25.5 & calcite-clayey siltstone & & & & & \\
\hline 19 & 44 & 123.8 & 39.9 & marlstone & 46 & 40 & 48.3 & 49.3 & marlstone & & & & & \\
\hline 20 & 45 & 128.2 & 51.8 & marlstone & 47 & 41 & 43.0 & 9.3 & clayey siltstone & & & & & \\
\hline 21 & 46 & 129.8 & 59.5 & marlstone & 48 & 43 & 26.1 & 42.5 & marlstone & & & & & \\
\hline
\end{tabular}

$\begin{array}{lllll}22 & 47 & 131.5 & 51.0 & \text { marlstone }\end{array}$

$\begin{array}{lllll}23 & 48 & 134.5 & 42.5 & \text { marlstone }\end{array}$

$\begin{array}{lllll}24 & 49 & 136.8 & 51.0 & \text { marlstone }\end{array}$

$\begin{array}{lllll}25 & 50 & 138.8 & 39.9 & \text { marlstone }\end{array}$

$\begin{array}{lllll}26 & 52 & 146.2 & 52.7 & \text { marlstone }\end{array}$

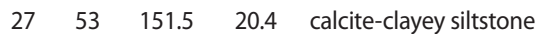

$\begin{array}{lllll}28 & 54 & 153.2 & 81.5 & \text { limestone }\end{array}$

$\begin{array}{lllll}29 & 56 & 157.8 & 16.1 \quad \text { calcite-clayey siltstone }\end{array}$

$\begin{array}{lllll}30 & 57 & 159.0 & 50.1 & \text { marlstone }\end{array}$

$\begin{array}{llll}31 & 58 & 161.9 & 12.7 \quad \text { calcite-clayey siltstone }\end{array}$ 
The lower unit in VA-1 corresponds to an alluvial system (not completely differentiated) and the upper part is re-deposited volcaniclastic rocks. The latter displays elements of debris flow, locally likely lahars, as being suddenly brought into the basin. In terms of sedimentology, the BCC corresponds to alluvial facies. Sedimentology of BCC additionally confirms the lithological difference of lake margins and reflects to a different way of contribution (alluvial flows or lahars). Subsidence during deposition of the $\mathrm{BCC}$ was more rapid than authigenic processes, such as lake infilling. Although the fossil remains are lacking, their early Middle Miocene age may be supposed according to similar lithological succession in other basins, e.g. in the Lake Popovac (SANT et al., 2017) and according to data from the Basic Geological Map, sheet Gornji Milanovac (FILIPOVIĆ et al., 1971).

\section{Unit B (lacustrine phase)}

After deposition of the BCC the lake was completely formed. The transgression took place and the input of medium- and coarsegrained terrigenous material decreased, particularly in the central part of the lake (where the boreholes were drilled). Coarser particles retained close to the margins forming the alluvial-lake and marginal-lake facies. Slightly higher amounts of such material were brought into the area of boreholes VA-1 and VA-2, due to the proximity of the basin margin. Finer-grained volcaniclastic material was synchronously brought into the basin revealing the first level of vitroclastic tuffs (see Fig. 3). Localized occurrences of tuff ( $232 \mathrm{~m}$ in VA-2) suggest that pyroclastic material arrived as lahars; otherwise a much broader area would be covered. According to KRSTIĆ et al. (2012) lake basins in Serbia are commonly lacking organisms with a calcium carbonate shell, as the lake water had to be acidic due to influence of volcanic activity. Lake acidification is additionally supported by the early soil development along with the role of atmospheric precipitation (RENBERG, 1990). Such a situation occurred during the period of deposition of the fine-grained clastites in shades of brick-red colour and green silty clays with carbonate concretions in alluvial sequences (interval 195-180 m in VA-2), reflecting the periodic subaerial conditions.

This unit (marlstone and fine-grained clastites) includes three lithofacies: (1) alluvial-lacustrine fine-grained clastites, (2) lacustrine marlstone, and (3) deltaic fine-grained clastites and sands.

(1) The upward decrease of grain-size and dimension of sand bodies in all three boreholes indicate that material was brought by muddy, turbidity flows. The sand bodies resembled the shape of channels through which sand and gravel have been distributed. The coarsening and thickening upward pattern is caused by the increasing and coeval exhumation during extension of a source area (ANDRIĆ et al., 2017). This gradually growing source area led to almost uni-directional sourcing of the basin (only from the north). The provenance ZFT (zircon fission tracks) age of $14.8 \pm$ $0.8 \mathrm{Ma}$ (Serravalian) for the coarse clastic sample from the Belanovica Basin, combined with some euhedral morphologies indicated the northern Bukulja pluton as the source area (STOJADINOVIĆ et al., 2017).

In the middle part of the basin the finest-grained, silty and clayey particles were deposited, and together with microcrystalline calcite allowed the formation of intrabasinal and lake facies, i.e. clastic-carbonate sediments. In terms of sedimentology this interval represents the alluvial-lacustrine facies. Constituents of sands, well-rounded pebbles originating from the volcanic complex and flysch sediments, together with the high content of magnesium (Mg) in VA-3 (up to 2.16\%) suggests the southern margin as the source area, as well as in VA-2 (up to $8.43 \%$; Supplementary Table). In VA-1 both margins were included (Fig. 5a). The contents of barium and strontium in fine-grained clastites is the highest in VA-1 (in given unit average Ba-115.20 ppm, Sr-809.63 ppm; Supplementary Table). This reflects either different amount of calcite-clayey siltstones, i.e. calcite where $\mathrm{Ba} 2+$ substitutes $\mathrm{Ca} 2+$ or more involvement of granitic rocks that tend to contain higher concentrations of Ba than the low-silica rocks (CULLERS, 1994). The slight increase of $\mathrm{Ba}+\mathrm{Sr}$ in VA-2 can suggest an increasing amount of fragments from lamprophyres or volcanic rocks with Ba-bearing biotite at least (e.g. HENDERSON, 1982; SHAW \& PENCZAK, 1996). A low to moderate Ba and Ti-bearing mica is thought to have been formed by magmas in a subduction-enriched subcontinental lithospheric mantle (JAQUES et al., 1986; THOMPSON et al., 1997). Such an interpretation is consistent with the already mentioned interaction between lamprophyric and granitoid magmas (PRELEVIĆ et al., 2004).

(2) During deposition of the marlstone lithofacies, which was the first truly intrabasinal facies, the basin was at least intermittently stratified. Contents of $\mathrm{Ba}+\mathrm{Sr}(500-2000 \mathrm{ppm})$ in the marlstones in VA-2 in respect to $\mathrm{Na}+\mathrm{K}(0.6-1.1 \%)$ could be explained by the substitution of $\mathrm{K}+$ by $\mathrm{Ba} 2+$ due to the presence of material from the southern margin (volcanic rocks; Fig. 5b). The increase of $\mathrm{Ba}+\mathrm{Sr}$ in respect to the almost uniform contents of $\mathrm{Na}+\mathrm{K}$ in marlstones in VA-1 and VA-2 is in agreement with the presence of hydrous $\mathrm{Mn}$ and Fe oxides, clay minerals and organic matter, which adsorb Ba2+ at higher $\mathrm{pH}$ (WEDEPOHL, 1978). The presence of sulfide (i.e. pyrite mineralization and carbonized flora) suggests periodically reduced conditions and an abundance of organic matter (recall the Fig. 4c).

A slight but progressive increase of $\mathrm{Th}+\mathrm{U}$ with the increase of $\mathrm{Na}+\mathrm{K}$ in VA-1 and VA-3 is in agreement with the increased contribution of material derived from the Bukulja and Brajkovac granites (Fig. 5c). It should be mentioned that in the Valjevo-Mionica basin there was a noted increase in the concentrations of uranium in coaly interbeds in Jelovik Village (KRSTIĆ et al., 2011).

The high concentrations of Th (3-16.7 ppm; Supplementary Table) could be due to the concentration of certain accessory minerals (e.g. zircon, monazite) in high-silica source rocks, i.e. granites (CULLERS, 1994). This element is (together with Sc) considered to be the most useful REE for inferring source rock composition as its distribution is not severely affected by secondary processes (CULLERS, 1994). In VA-2 these values do not correlate due to the variable abundance of fragments from felsic rocks and flysch clastites.

(3) The final lithofacies (fine-grained clastites and sands) of this unit received material from both margins. Alluvial systems from the South brought enormous amounts of coarsergrained terrigenous compounds (gravel and sand) into the basin resembling a deltaic model of deposition, i.e. alluvial-lake facies with well-evolved delta. Delta comprised a delta plain, delta front and prodelta and it was intermittently flooded by a lake (constructive and destructive phase).

\section{Unit C (alluvial-lacustrine phase)}

The youngest recognized unit is termed sand, gravel, sandstone and fine-grained clastites. Intraformational fragments of sandstone, originating from unit B (marlstone and fine-grained clastites) shows that the former sands were cemented by calcite, most probably mobilized internally from the same unit. Constituents of dominating sands and gravels in VA-1 and VA-2 imply almost exclusive origin from the northern margin, i.e. from metamorphic 
and granitoid rocks. This could be a consequence of tilting to the south and uplift of the northern area leaving the Bukulja and Brajkovac massifs exposed to erosion. The high percentage of quartz relative to other minerals suggests that all the analyzed sandstones are most likely first cycle sediments, i.e. products of intense chemical weathering (CULLERS \& PODKOVYROV, 2002). Such an inference is additionally supported by the good correlation of boron (B) and lithium (Li), particularly in VA-2, where the lake depositional environment lasted the longest. In terms of sedimentology these sediments are considered to represent alluvial-lacustrine facies. Local occurrences of lenticular bodies of sand or gravel on a metre to decametre scale resemble the channel forms by which particles were distributed.

Sands and gravels comprise this unit in column VA-3, too. Their boundary with the previous unit is marked by a sequence of yellowish-red coarse-grained gravels. The colour-variations throughout the unit reflect a shallow, oxygen-rich environment and the gradual closure of the basin. The presence of a palaeosol horizon with two levels of carbonate concretions in finer-grained clastites indicates periodic subaerial conditions and supports the previous conclusion. The lower part of the unit includes alluviallacustrine intervals (polymict gravels) with the notable presence of fragments from metamorphic rocks.

The highest boron contents usually occur in sedimentary beds associated with volcanic activity, as in the volcaniclastic rocks in VA-1 (unit B, interval 170-199m; values 87-172 ppm; Supplementary Table). In contrast, the tuffaceous rocks in VA-2 display similar behaviour as sedimentary rocks in VA-1 and VA-3 - uniform B and slight increased Li (Fig. 5 d, e). Most of the boron content of sands and sandstones can be attributed to the pres-
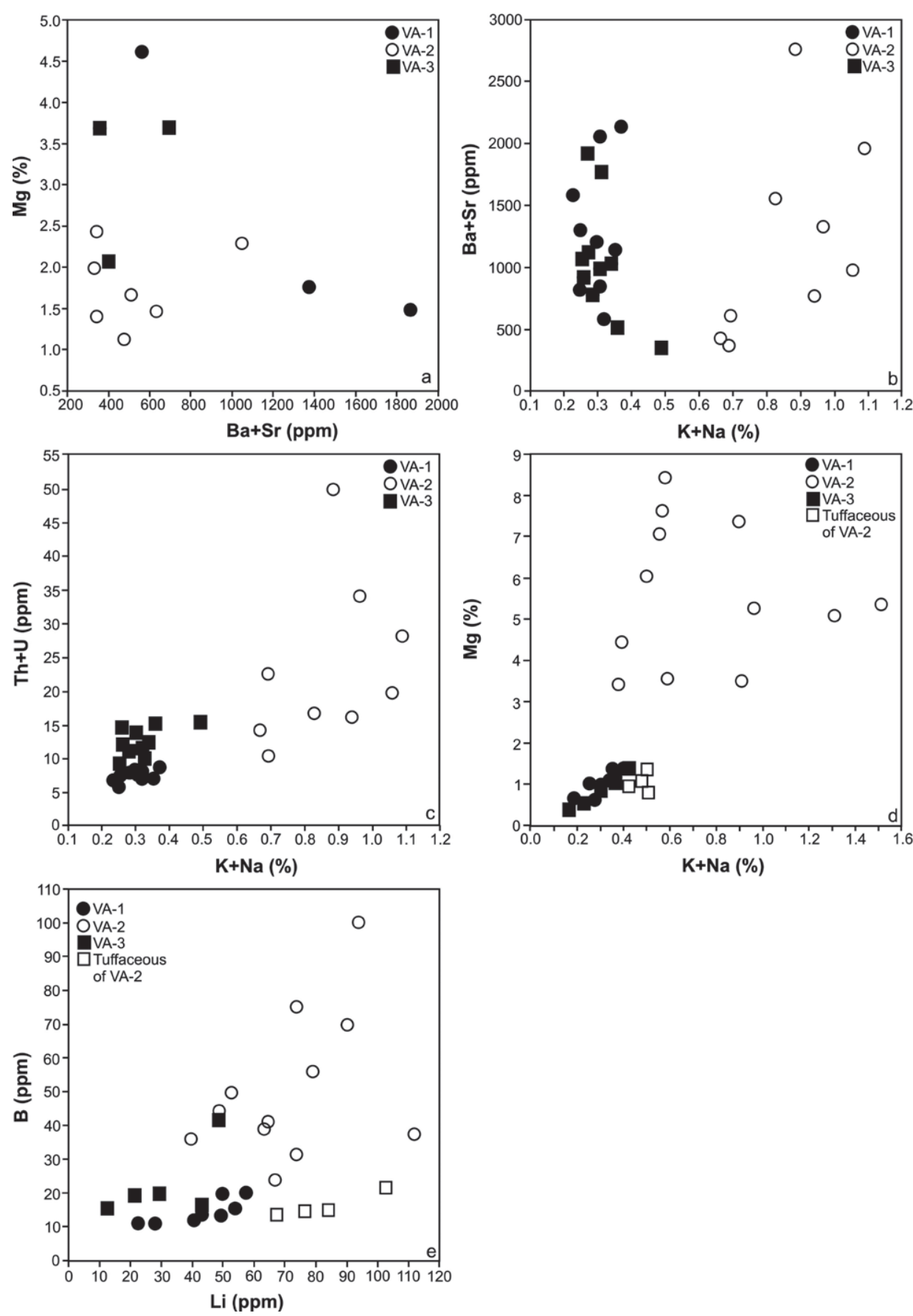

Figure 5. Distribution of selected elements in distinguished lithofacies. 
ence of tourmaline or to higher proportions of clay (HARDER, 1970). In finer-grained sediments its concentration varies inversely with grain size, thus the highest values are found in the finest fractions. Boron, together with sodium is considered a good geochemical indicator of marine (saline) or fresh-water environments, as its content in sediment depends primarily on the type of rock involved (HARDER, 1970). The low Na and uniform B reflects a lacustrine or fresh-water environment.

\section{Age}

The availability of data on lacustrine sediments in Serbia, regarding their age have until recently been scarce or only presented in local publications. The Serbian Lake sediments are older than the marine Middle Badenian, as they lie concordantly below it.

As they are also overlain by marine deposits of Late Badenian/Sarmatian age the lacustrine sediments were generally considered Early to Middle Badenian. The Valjevo-Mionica-Belanovica graben formed during the Ottnangian-Karpatian but later divided into the Valjevo-Mionica (west) and Belanovica (to the east) basins (MAROVIĆ et al., 2007). Index fossils are lacking in the Belanovica lake sediments but the presence of freshwater Melanopsis support their Middle Miocene age, as the earliest record of it dates back in the late Early Miocene (NEUBAUER et al., 2016). The lack of marine sediments in the Belanovica basin suggests that deposition ceased before the Late Badenian/ Sarmatian when the Valjevo-Mionica basin was ingressed by marine water. The new data obtained for Lake Popovac reflect that the development of the Serbian lakes started around $14.5 \mathrm{Ma}$ ago, in the Langhian, which corresponds to the Early Badenian Stage of the Central Paratethys (SANT et al., 2017).

The fission-track analysis is potentially useful for unraveling the age of the studied lacustrine sediments.

\section{CONCLUSIONS}

The Belanovica Lake developed during the Neogene in the area between the Brajkovac and Bukulja Mountains (granitoid and low-grade metamorphic rocks) to the North, and a broad area covered by Albian-Cenomanian flysch, Jurassic ultramafics and the Neogene volcanic mass of Slavkovica to the South. Alluvial and occasionally torrential flows coming from the South were responsible for the onset of deposition.

The lake bottom dipped southeast periodically revealing parts of the lake sediments and exposing them to subaerial conditions. The alluvial-lacustrine and marginal-lacustrine facies retained close to the basin margin, whereas the finest-grained, silty and clayey particles arrived in the central and deepest part of the basin contributing there to the intrabasinal open-lacustrine facies. The alluvial flows from both margins contributed more than the synchronous volcanism to basin infilling, which itself was responsible for increasing the lake-water acidity. The flows from the single northern margin into the western area (VA-1 and VA-2) indicate the gradual closure of the basin. The eastern area (VA-3) was frequently exposed to subaerial conditions giving rise to palaeosol development.

The three-stage evolution of the Belanovica basin, inferred from integrated chemical and petrographic data, was controlled by palaeorelief of the pre-Neogene basement, erosion rate, and intensity of alluvial flows. The influence of volcanic activity should also be taken into consideration. Lake sediments inherited signatures of the source rocks at the basin margins.

The whole succession, lacking age-diagnostic fossils, was tentatively correlated with the Middle Miocene. Tuffaceous rocks could hold the potential for unraveling the age of these lake sediments, as well as the fission-track low-temperature thermochronology.

\section{ACKNOWLEDGMENT}

This research has been supported by the Serbian Ministry of Science, Project No 176019. The authors are indebted to colleagues from the company "Ultra Balkans d.o.o." for permission to publish a part of their research results. We would like to thank the journal reviewers Oleg MANDIĆ (Vienna) and an unknown reviewer for their careful revision of the manuscript. Their effort is gratefully acknowledged. We are indebted to Ljupko RUNDIĆ (Belgrade) for providing palaeontological analysis.

\section{REFERENCES}

ALMENDINGER, J.E. (1993): A groundwater model to explain past lake levels at Parkers Prairie, Minnesota, USA. Holocene, 3, 105-115. doi: 10.1177/ 095968369300300202

ANDRIĆ, N., SANT, K., MATENCO, L., MANDIĆ, O., TOMLJENOVIĆ, B., PAVELIĆ, D, HRVATOVIĆ, H., DEMIR, V. \& OOMS, J. (2017): The link between tectonics and sedimentation in asymmetric extensional basins: Inferences from the study of the Sarajevo-Zenica Basin.- Marine and Petroleum Geology, 83, 305-332. doi: 10.1016/j.marpetgeo.2017.02.024

ANĐELKOVIĆ, M., EREMIJA, M., PAVLOVIĆ, M., ANĐELKOVIĆ, J. \& MITROVIĆ-PETROVIĆ, J. (1991): Paleogeografija Srbije, Tercijar [Palaeogeography of Serbia, Tertiary - in Serbian] (ed. M. Anđelković), 237 p., Beograd.

BINFORD, M.W. \& DEEVEY, E.S. (1983): Palaeolimnology: an historical perspective on lacustrine ecosystems.-Ann. Rev. Ecol. Syst., 14/1, 255-286. doi: 10.1146/annurev.es.14.110183.001351

COHEN, A.S. (2003). Palaeolimnology: the history and evolution of lake systems.- Oxford University Press, New York.

COX, P.A. (1995): The Elements on Earth.- Oxford University Press, 287 p.

CULLERS, R.L. (1994): The chemical signature of source rocks in size fractions of Holocene stream sediment derived from metamorphic rocks in the Wet Mountains region, Colorado, USA.- Chemical Geology, 113, 327-343. doi: 10.1016/00092541(94)90074-4

CULLERS, R.L. (2000): The geochemistry of shales, siltstones and sandstones of Pennsylvanian-Permian age, Colorado, USA: Implications for provenance and metamorphic studies.- Lithos, 51, 181-203. doi: 10.1016/S0024 - 4937(99)00063-8

CULLERS, R.L., BARRETT, T., CARLSON, R. \& ROBINSON, B. (1987): Rare earth element and mineralogic changes in Holocene soil and stream sediment: a case study in the Wet Mountains, Colorado, USA.- Chem. Geol., 63, 275-297. doi: 10.1016/0009-2541(87)90167-7

CULLERS, R.L. \& PODKOVYROV, V.N. (2002): The source and origin of terrigenous sedimentary rocks in the Mesoproterozoic UI group, southern Russia.- Precambrian Research, 117, 157-183. doi: 10.1016/S0301-9268(02)00079-7

CVETKOVIĆ, V., PRELEVIĆ, D. \& PÉCSKAY, Z. (2000): Lamprophyric rocks of the Miocene eruptive complex (central Serbia, Yugoslavia).- Acta Geologica Hungarica, 43/1, 25-41. ISSN 0236-5278

CVETKOVIĆ, V., POLI, G., CHRISTOFIDES, G., KORONEOS, A., PÉCSKAY, Z., RESIMIĆ-ŠARIĆ, K. \& ERIĆ, V. (2007): The Miocene granitoid rocks of Mt. Bukulja (central Serbia): evidence for Pannonian extension-related granitoid magmatism in the northern Dinarides.- European Journal of Mineralogy, 19, 513-532. doi: 10.1127/0935-1221/2007/0019-1736

CVETKOVIĆ, V., POLI, G. \& PRELEVIĆ, D. (2001): Eruptive history and low-pressure evolution of the Early Miocene Borač eruptive complex (Central Serbia).- In: DOWNES, H. \& VASELLI, O. (eds.): Tertiary magmatism in the Dinarides Balkan Peninsula, Acta Vulcanologica, 13/(1/2), 127-143.

DIGERFELDT, G., ALMENDINGER, J.E. \& BJORCK, S. (1993): Reconstruction of past lake levels and their relation to groundwater hydrology in the Parkers Prairic sandplain, west-central Minnesota.- Palaeogeography, Palaeoclimatology, Palaeoecology, 94, 99-118. doi: 10.1016/0031-0182(92)90115-L

DOLIĆ, D. (1986): Neki aktuelni problemi daljeg istraživanja tercijarnih naslaga SR Srbije [Some actual problems for further studies of Tertiary deposits in SR Serbia].XI Kongres geologa Jugoslavije, 2, 61-68, Tara.

ENGSTROM, D.R., FRITZ, S.C., ALMENDINGER, J.E. \& JUGGINS, S. (2000): Chemical and biological trends during lake evolution in recently deglaciated terrain.- Nature, 408, 161-166. doi: 10.1038/35041500

FILIPOVIĆ, I., PAVLOVIĆ, Z., MARKOVIĆ, B., RODIN, V., MARKOVIĆ, O., GAGIĆ, N., ATIN, B. \& MILIĆEVIĆ, M. (1971): Osnovna geološka karta SFRJ 1:100.000, list Gornji Milanovac L 34-137 [Basic Geologic Map of SFRY 1:100 000, Gornji Milanovac sheet].- Savezni geološki zavod, Beograd. 
FOLK, R.L., ANDREWS, P.B. \& LEWIS, D.W. (1970): Detrital sedimentary rock classification and nomenclature for use in New Zealand, New Zealand.- Journal of Geology and Geophysics, 13/4, 937-968. doi: 10.1080/00288306.1970.10418211

FRITZ, C.S. (1996): Palaeolimnological records of climatic change in North America.Limnology and Oceanography, 41/5, 882-889. doi: 10.4319/lo.1996.41.5.0882

FRITZ, C.S. (2008): Deciphering climatic history from lake sediments.- Journal of Palaeolimnology, 39, 5-16. Springer. doi: 10.1007/s10933-007-9134-x

HAKSTEGE, A.L., KROONENBERG, S.B. \& VAN WIJCK, H. (1993): Geochemistry of Holocene clays of the Rhine and Mouse rivers in the central-eastern Netherlands.- Geol. Mijnbouw, 71, 301-315.

HARZHAUSER, M. \& MANDIĆ, O. (2008): Neogene lake systems of Central and South-Eastern Europe: Faunal diversity, gradients and interrelations.- Palaeogeography, Palaeoclimatology, Palaeoecology, 260, 417-434. doi: 10.1016/j.palaeo.2007.12.013

HARDER, H. (1970): Boron content of sediments as a tool in facies analysis.- Sedimentary geology, 4/(1-2), 153-175. doi: 10.1016/0037-0738(70)90009-6

HENDERSON, P. (1982): Inorganic Geochemistry.- Pergamon Press, Oxford, U.K., 353 p.

HUISMAN, D.J. \& KIDEN, P. (1997): The geochemical record of Upper Cenozoic sedimentation history in the Southern Netherlands.- Geol. Mijnbouw, 76, 277-291. doi: 10.1023/A: 1003212721020

HICKMAN, M. \& WHITE, J.M. (1989): Late Quaternary palaeoenvironment of Spring lake, Alberta, Canada.- Journal of Palaeolimnology, 2, 305-317. doi: 10.1007/ BF00195478

JAQUES, A.L., LEWIS, C.D. \& SMITH, C.B. (1986): The kimberlites and lamproites of Western Australia.- Geol-Surv. Western Australia Bull., 132, 268 p.

JOVANOVIĆ, O., GRGUROVIĆ, D. \& ZUPANČIČ, N. (1992): Kontinentalno-jezersko i marinsko-brakični neogen Valjevskog i Tamnavskog basena [Continental-lacustrine and marine-brackish Neogene in the Valjevo and Tamnava basins].- Vesnik Geozavoda, Beograd.

KNEŽEVIĆ, V., KARAMATA, S. \& CVETKOVIĆ, V. (1994): Tertiary granitic rocks along the southern margin of the Pannonian Basin.- Acta Mineralogica-Petrographica, Szeged, 35, 71-80

KRSTIĆ, N., DUMURDŽANOV, N., OLUJIĆ, J., VUJNOVIĆ, L. \& JANKOVIĆGOLUBOVIĆ, J. (2001): Interbedded tuff and bentonite in the Neogene lacustrine sediments of the central part of the Balkan Peninsula. A Review.- Acta Vulcanologica, 13, 91-99.

KRSTIĆ, N., SAVIĆ, L., JOVANOVIĆ, G. \& BODOR, E. (2003): Lower Miocene lakes of the Balkan Land.- Acta Geologica Hungarica, 46, 291-299. doi: 10.1556/ AGeol.46.2003.3.4

KRSTIĆ, N., SAVIĆ, L. \& JOVANOVIĆ, G. (2012): The Neogene lakes on the Balkan land.-Annales Géologiques de la Peninsule Balkanique, LXXIII, 37-60. doi: 10.2298/GABP1273001R

MAROVIĆ, M., KRSTIĆ, N., STANIĆ, S., CVETKOVIĆ, V. \& PETROVIĆ, M. (1999): Evolucija neogenih sedimentacionih prostora centralnih delova balkanskog poluostrva [Evolution of the Neogene sedimentation area in the Central Balkan Peninsula].- Radovi Geoinstituta, 36, 25-94, Beograd.

MAROVIĆ, M., TOLJIĆ, M., RUNDIĆ, LJ. \& MILIVOJEVIĆ, J. (2007): Neoalpine Tectonics of Serbia.-Serbian Geological Society, Series Monographie, 71-78. doi: $10.2298 / \mathrm{GABP} 1273099 \mathrm{C}$

MATENCO, L. \& RADIVOJEVIC, D. (2012): On the formation and evolution of the Pannonian Basin: constraints derived from the structure of the junction area between the Carpathians and Dinarides.- Tectonics, 31/6, TC6007. doi: 10.1029/ 2012TC003206

MOURA, M.L. \& KROONENBERG, S.B. (1990): Geochemistry of Quaternary fluvial and eolian sediments in the southeastern Netherlands.- Geol. Mijnbouw, 69, 359373

OBRADOVIĆ, J., DJURDJEVIĆ-COLSON, J. \& VASIĆ, N. (1997): Phytogenic lacustrine sedimentation-oil shales in Neogene from Serbia, Yugoslavia.- Journal of Palaeolimnology, 18, 351-364.
OBRADOVIĆ, J. \& DIMITRIJEVIĆ, R. (1978): Piroklastične stene sa analcimom iz "Slanačke serije" Beogradskog dunavskog ključa [Pyroclastic rocks with Analcime from the Slanci Series of the Danube River Band (Dunavski ključ) near Belgrade - in Serbian].-Annales Géologiques de la Peninsule Balkanique, XLII, 483-492, Beograd.

OBRADOVIĆ, J. VASIĆ, N. (2007): Neogene lacustrine basins from Serbia.- Monographs, DCLXII, Serbian Academy of Sciences and Arts, $310 \mathrm{p}$

PAVELIĆ, D. (2001): Tectonostratigraphic model for the North Croatian and North Bosnian sector of the Miocene Pannonian Basin System.- Basin Research, 13, 359 376. doi: 10.1046/j.0950-091x.2001.00155.x

PRELEVIĆ, D., CVETKOVIĆ, V. \& FOLEY, S.F. (2001): Composite igneous intrusions from Serbia: two case studies of interaction between lamprophyric and granitoid magmas.- In: DOWNES, H. \& VASELLI, O. (eds.): Tertiary Magmatism in the Dinarides Balkan Peninsula: Acta Vulcanologica, 13/1-2, 145-157. doi: 10.1400/ 19071

PRELEVIĆ, D., FOLEY, S.F., CVETKOVIĆ, V. \& ROMER, R.L. (2004): Origin of minette by mixing of lamproite and felsic magmas in Veliki Majdan, Serbia.- Journal of Petrology, 45/4, 759-792. doi: 10.1093/petrology/egg109

RABRENOVIĆ, D., VASIĆ, N., MITROVIĆ-PETROVIĆ, J., RADULOVIĆ, V., RADULOVIĆ, B. \& SREĆKOVIĆ-BATOĆANIN, D. (2002): The Middle Cenomanian basal series of Planinica, Western Serbia.-Annales Géologiques de la Peninsule Balkanique, 64 (2001), 13-43. doi: 10.2298/GABP0264013R

RENBERG, I. (1990): A 12,600 year perspective on the acidification of Lilla Oresjon, southwest Sweden.- Phil. Trans. Roy. Soc. Lond., B 327, 357-361.

SANT, K., MANDIC, O., RUNDIĆ, L., KUIPER, K.F., \& KRIJGSMAN, W. (2017). Age and evolution of the Serbian Lake System: integrated results from Middle Miocene Lake Popovac.- Newsletters on Stratigraphy, 51/1. doi: 10.1127/nos/2016/0360

SHAW, C.S.J. \& PENCZAK, R.S. (1996): Barium- and titanium- rich biotite and hlogopite from the western and eastern gabbro, Coldwell alkaline Complex, northwestern Ontario.- The Can. Mineral., 34, 967-975.

STANLEY, C., JONES, G., RUMSEY, M., BLAKE, C., ROBERTS, A., STIRLING, J., CARPENTER, G., WHITFIELD, P., GRICE, J. \& LEPAGE, Y. (2007): Jadarite, $\mathrm{LiNaSiB}_{3} \mathrm{O}_{7}(\mathrm{OH})$, a new mineral species from the Jadar Basin, Serbia.- Eur. J. Mineral., 19, 575-580. doi: 10.1127/0935-1221/2007/0019-1741

STOJADINOVIĆ, U., MATENCO, L., ANDRIESSEN, P., TOLJIĆ, M., RUNDIĆ, LJ. \& DUCEA, M. (2017): Structure and provenance of Late Cretaceous-Miocene sediments located near the NE Dinarides margin: Inferences from kinematics of orogenic building and subsequent extensional collapse.- Tectonophysics, 710-711, 184-204. doi: 10.1016/j.tecto.2016.12.021

TALBOT, M.R. \& KELTS, K. (1989): The Phanerozoic records of lacustrine basins and their environmental signals. - Palaeogeography, Palaeoclimatology, Palaeoecology, 70/1-3, 1-5. Elsevier. doi: 10.1016/0031-0182(89)90076-X

THOMPSON, R.N., VELDE, D., LEAT, P.T., MORRISON., M.A., MITCHELL, J.G., DICKIN., A.P. \& GIBSON., S.A. (1997): Oligocene lamproite containing an Alpoor, Ti-rich biotite, Middle Park, northwest Colorado, USA.-Mineral. Mag., 61, 557-572. doi: 10.1180/minmag.1997.061.407.08

TRIVIĆ, B., CVETKOVIĆ, V., SMILJANIĆ, B. \& GAJIĆ, R. (2010): Deformation pattern of the Palaeozoic units of the Tethyan suture in the Central Balkan Peninsula: a new insight from study of the Bukulja-Lazarevac Palaeozoic unit (Serbia).Ofioliti, 35/1, 21-32. doi: 10.2298/GABP1374047V

VASIĆ, N., KOSTIĆ, M., DURIĆ, S. \& RABRENOVIĆ, D. (2001): Visoko magnezijumske smektitske gline u bazalnoj seriji alb-cenomana Planinice (zapadna Srbija) [High-smectite clays in the basal Albian-Cenomanian series in Planinica (Western Serbia)].- Mineralogija, godišnjak JAM, 3, 78-84. Beograd.

WEDEPHOL, K.H. (1978): Handbook of Geochemistry. II/4, Springer-Verlag-BerlinHeidelberg-New York.

WHITFIELD, P., PAGE. L.Y., GRICE, J., STANLEY, C., JONES, G., RUMSEY, M., BLAKE, C., ROBERTS, A., STIRLING, J. \& CARPENTER, G. (2007): $\mathrm{LiNaSiB}_{3} \mathrm{O}_{7}(\mathrm{OH})$ - novel structure of the new borosilicate mineral jadarite determined from laboratory powder diffraction data.- Acta Crystallographica, B63, 396-401. doi: 10.1107/50108768107010130 


\section{Supplementary Table}

Contents of indicative chemical elements in the Belanovica basin lake deposits in ppm or in \%, (as indicated), including detection limit(s). Lithofacies are marked as in the text (A, B and C). Shaded area considers volcaniclastic rocks.

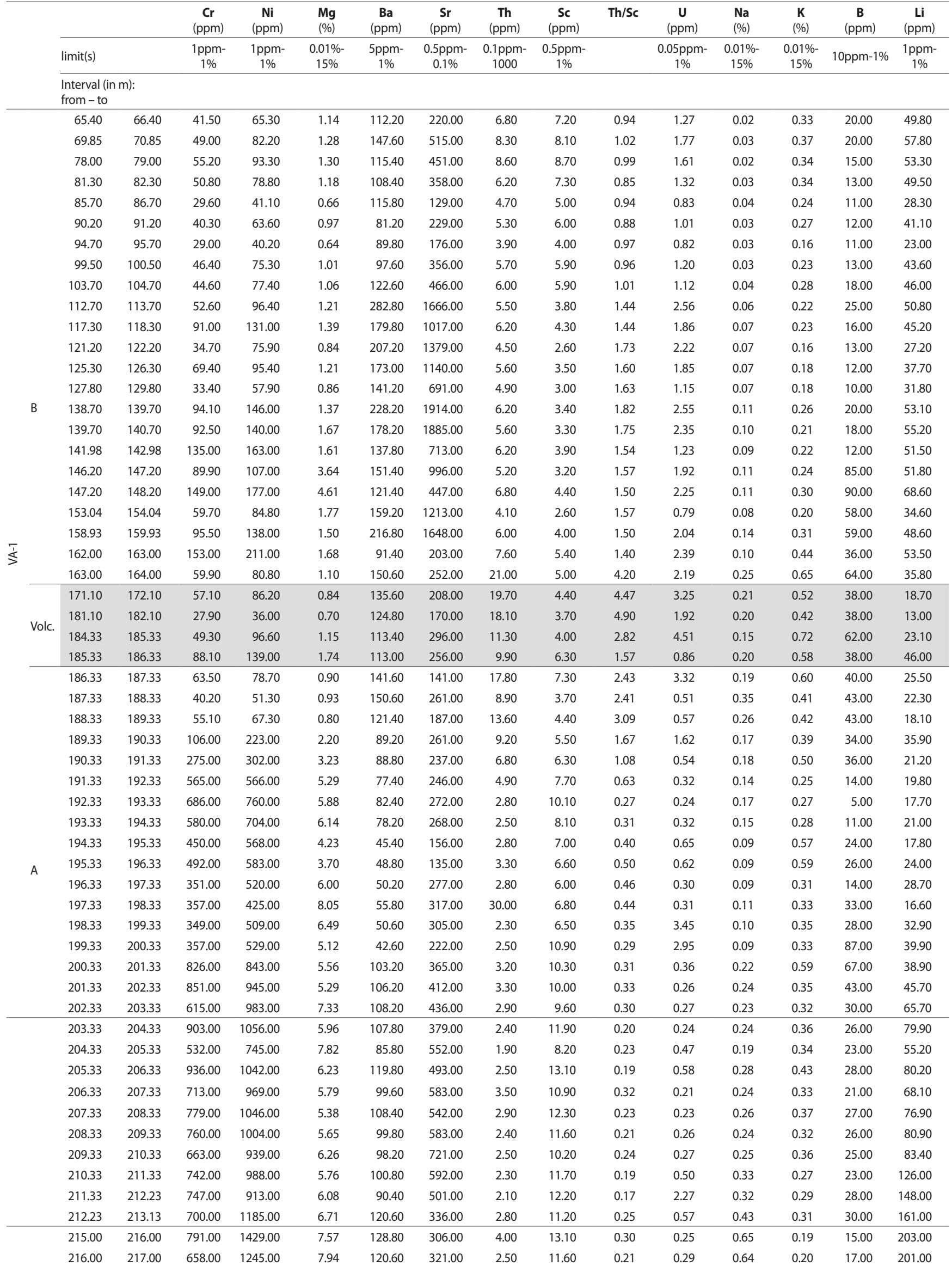




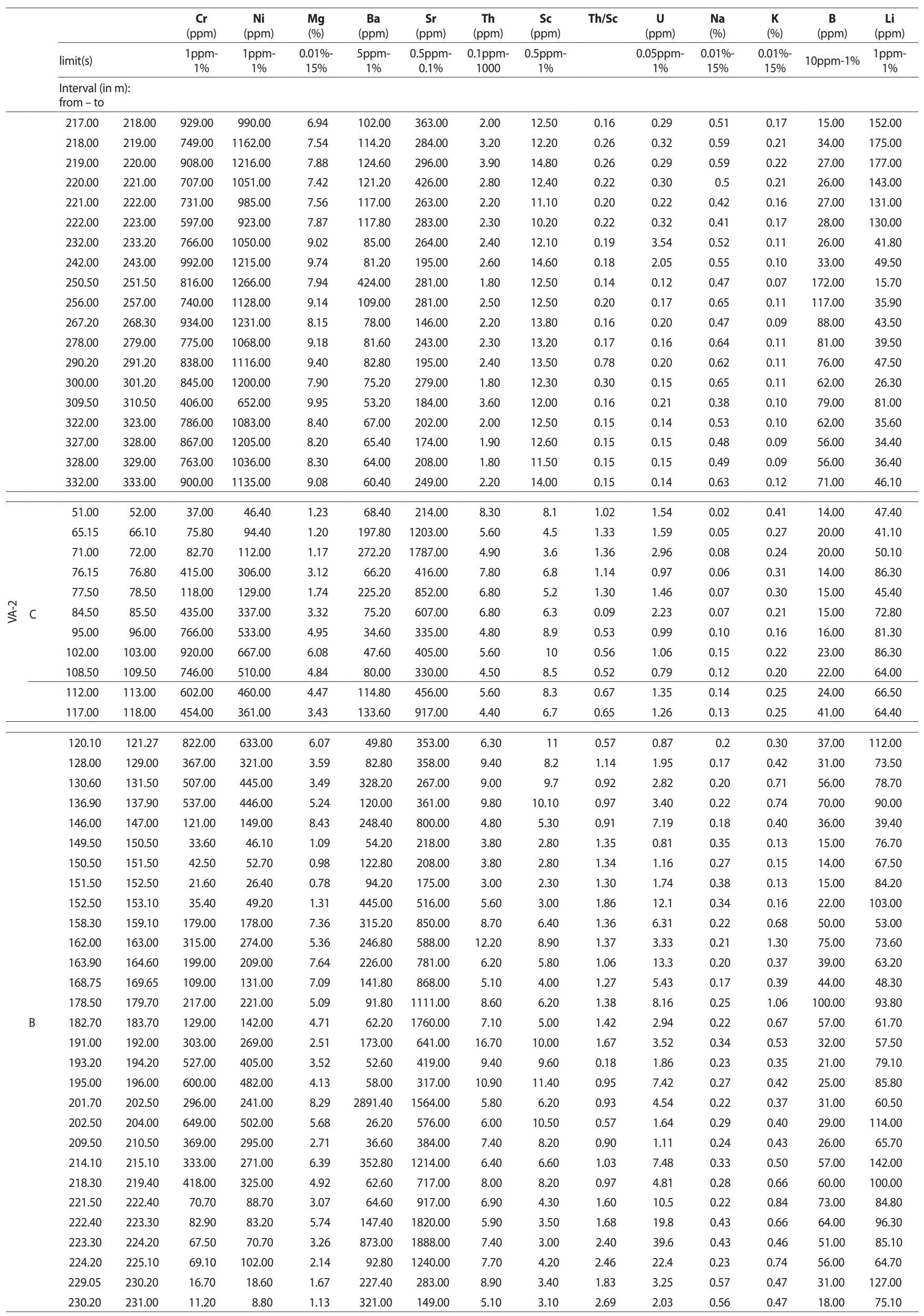




\begin{tabular}{|c|c|c|c|c|c|c|c|c|c|c|c|c|c|c|c|c|}
\hline & & & & $\begin{array}{c}\mathrm{Cr} \\
(\mathrm{ppm})\end{array}$ & $\begin{array}{c}\mathbf{N i} \\
(\mathrm{ppm})\end{array}$ & $\begin{array}{l}\mathbf{M g} \\
(\%)\end{array}$ & $\begin{array}{c}\text { Ba } \\
(\mathrm{ppm})\end{array}$ & $\begin{array}{c}\text { Sr } \\
(\mathrm{ppm})\end{array}$ & $\begin{array}{c}\text { Th } \\
\text { (ppm) }\end{array}$ & $\begin{array}{c}\text { Sc } \\
(\mathrm{ppm})\end{array}$ & Th/Sc & $\underset{(p p m)}{\mathbf{U}}$ & $\begin{array}{l}\mathrm{Na} \\
(\%)\end{array}$ & $\begin{array}{c}\mathbf{K} \\
(\%)\end{array}$ & $\begin{array}{c}\text { B } \\
(\mathrm{ppm})\end{array}$ & $\begin{array}{c}\mathbf{L i} \\
(\mathrm{ppm})\end{array}$ \\
\hline & & \multicolumn{2}{|l|}{ limit(s) } & $\begin{array}{c}1 \mathrm{ppm}- \\
1 \%\end{array}$ & $\begin{array}{c}1 \mathrm{ppm}- \\
1 \%\end{array}$ & $\begin{array}{c}0.01 \%- \\
15 \%\end{array}$ & $\begin{array}{c}5 p p m- \\
1 \%\end{array}$ & $\begin{array}{c}0.5 \mathrm{ppm}- \\
0.1 \%\end{array}$ & $\begin{array}{c}0.1 \mathrm{ppm}- \\
1000\end{array}$ & $\begin{array}{c}0.5 \mathrm{ppm}- \\
1 \%\end{array}$ & & $\begin{array}{c}0.05 \mathrm{ppm}- \\
1 \%\end{array}$ & $\begin{array}{c}0.01 \%- \\
15 \%\end{array}$ & $\begin{array}{c}0.01 \%- \\
15 \%\end{array}$ & 10ppm-1\% & $\begin{array}{c}1 \mathrm{ppm}- \\
1 \%\end{array}$ \\
\hline & & \multicolumn{15}{|c|}{$\begin{array}{l}\text { Interval (in m): } \\
\text { from - to }\end{array}$} \\
\hline & & 231.00 & 231.80 & 8.50 & 5.60 & 1.48 & 360.20 & 274.00 & 8.80 & 3.20 & 1.64 & 3.02 & 0.64 & 0.49 & 24.00 & 108.00 \\
\hline & & 231.80 & 232.45 & 13.80 & 15.40 & 2.30 & 453.60 & 592.00 & 14.70 & 5.00 & 2.75 & 6.21 & 0.73 & 0.49 & 30.00 & 152.00 \\
\hline & & 240.00 & 241.00 & 213.00 & 199.00 & 2.01 & 42.40 & 292.00 & 11.50 & 6.40 & 2.67 & 2.24 & 0.19 & 0.58 & 45.00 & 54.90 \\
\hline & & 247.30 & 248.50 & 357.00 & 294.00 & 2.42 & 37.00 & 303.00 & 11.00 & 9.50 & 1.79 & 1.61 & 0.26 & 0.44 & 29.00 & 60.70 \\
\hline & & 252.00 & 253.20 & 111.00 & 128.00 & 1.40 & 48.80 & 299.00 & 12.70 & 5.80 & 2.19 & 2.55 & 0.26 & 0.55 & 36.00 & 34.60 \\
\hline \multirow{7}{*}{\multicolumn{2}{|c|}{ A }} & 258.20 & 259.20 & 79.10 & 117.00 & 1.13 & 63.20 & 270.00 & 16.00 & 6.00 & 2.66 & 7.14 & 0.28 & 0.63 & 47.00 & 30.90 \\
\hline & & 259.20 & 260.20 & 64.80 & 105.00 & 1.10 & 52.80 & 185.00 & 14.00 & 6.10 & 2.29 & 1.36 & 0.27 & 0.62 & 34.00 & 31.40 \\
\hline & & 270.50 & 271.50 & 247.00 & 79.00 & 0.98 & 178.60 & 267.00 & 17.80 & 14.00 & 1.27 & 4.54 & 0.40 & 0.45 & 43.00 & 19.80 \\
\hline & & 273.50 & 274.50 & 75.30 & 34.50 & 0.97 & 114.80 & 206.00 & 24.30 & 8.90 & 2.73 & 5.13 & 0.33 & 0.61 & 37.00 & 17.20 \\
\hline & & 277.60 & 278.60 & 10.60 & 5.20 & 0.54 & 82.20 & 65.50 & 29.80 & 7.50 & 4.01 & 3.24 & 0.17 & 0.44 & 14.00 & 6.60 \\
\hline & & 287.00 & 288.00 & 9.80 & 4.40 & 0.58 & 115.20 & 58.00 & 28.90 & 7.20 & 4.19 & 2.75 & 0.18 & 0.48 & 5.00 & 13.10 \\
\hline & & 293.00 & 294.00 & 9.40 & 4.40 & 0.55 & 100.20 & 56.00 & 28.50 & 6.80 & 0.95 & 3.99 & 0.21 & 0.55 & 5.00 & 13.50 \\
\hline \multirow{8}{*}{\multicolumn{2}{|c|}{ C }} & 84.50 & 85.50 & 32.40 & 43.90 & 0.93 & 96.40 & 140.00 & 6.80 & 7.1 & 1.04 & 3.21 & 0.02 & 0.34 & 18.00 & 36.30 \\
\hline & & 87.50 & 88.50 & 19.00 & 21.80 & 0.47 & 80.00 & 101.00 & 4.70 & 3.5 & 0.95 & 1.06 & 0.03 & 0.16 & 12.00 & 18.50 \\
\hline & & 89.50 & 90.50 & 51.60 & 79.10 & 1.14 & 119.20 & 297.00 & 9.50 & 8.2 & 1.34 & 1.73 & 0.03 & 0.36 & 18.00 & 47.80 \\
\hline & & 93.20 & 94.20 & 39.20 & 50.00 & 1.12 & 92.60 & 174.00 & 8.80 & 8.4 & 1.15 & 1.54 & 0.02 & 0.4 & 14.00 & 55.30 \\
\hline & & 96.20 & 97.20 & 36.20 & 49.30 & 1.04 & 86.80 & 196.00 & 9.10 & 7.9 & 1.04 & 1.81 & 0.02 & 0.35 & 12.00 & 48.10 \\
\hline & & 105.20 & 106.20 & 32.90 & 47.40 & 1.10 & 81.60 & 167.00 & 8.20 & 7.3 & 1.15 & 1.46 & 0.02 & 0.34 & 10.00 & 48.00 \\
\hline & & 109.70 & 110.70 & 23.80 & 32.90 & 0.76 & 120.00 & 134.00 & 6.00 & 5.4 & 1.12 & 1.12 & 0.03 & 0.27 & 5.00 & 33.00 \\
\hline & & 118.70 & 119.70 & 15.30 & 24.80 & 0.32 & 30.00 & 35.50 & 2.50 & 1.50 & 1.11 & 1.84 & 0.02 & 0.10 & 18.00 & 8.00 \\
\hline \multirow{16}{*}{\multicolumn{2}{|c|}{$\stackrel{m}{\lessgtr}$}} & 128.20 & 129.20 & 22.00 & 32.40 & 0.66 & 68.80 & 93.80 & 5.70 & 4.40 & 1.29 & 0.90 & 0.02 & 0.22 & 18.00 & 21.10 \\
\hline & & 136.70 & 137.70 & 24.90 & 37.90 & 0.82 & 64.40 & 108.00 & 6.30 & 5.30 & 1.18 & 1.12 & 0.02 & 0.27 & 18.00 & 29.30 \\
\hline & & 154.70 & 155.70 & 35.40 & 54.20 & 1.00 & 62.80 & 133.00 & 6.90 & 6.50 & 1.06 & 0.98 & 0.02 & 0.35 & 15.00 & 43.00 \\
\hline & & 161.20 & 162.20 & 18.60 & 25.10 & 0.38 & 39.80 & 86.40 & 4.00 & 2.50 & 1.60 & 0.83 & 0.03 & 0.13 & 14.00 & 12.50 \\
\hline & & 168.20 & 169.20 & 39.10 & 77.50 & 1.16 & 72.00 & 298.00 & 9.60 & 8.70 & 1.10 & 1.67 & 0.03 & 0.39 & 42.00 & 48.60 \\
\hline & & 173.20 & 174.20 & 68.80 & 126.00 & 1.39 & 192.40 & 601.00 & 5.70 & 5.10 & 1.11 & 1.90 & 0.04 & 0.25 & 33.00 & 37.30 \\
\hline & & 180.50 & 181.50 & 49.50 & 90.00 & 0.94 & 246.60 & 1716.00 & 4.40 & 3.70 & 1.19 & 2.44 & 0.06 & 0.22 & 32.00 & 27.60 \\
\hline & & 186.78 & 187.28 & 28.10 & 51.60 & 0.71 & 594.00 & 333.00 & 13.70 & 3.00 & 4.53 & 4.53 & 0.03 & 0.23 & 16.00 & 40.00 \\
\hline & & 190.70 & 191.70 & 52.50 & 97.20 & 1.25 & 123.00 & 901.00 & 6.40 & 4.50 & 1.42 & 1.86 & 0.07 & 0.26 & 20.00 & 39.50 \\
\hline & & 194.00 & 195.00 & 47.20 & 84.80 & 1.04 & 76.00 & 444.00 & 7.30 & 5.50 & 1.32 & 2.08 & 0.08 & 0.28 & 21.00 & 31.20 \\
\hline & & 199.30 & 200.30 & 71.70 & 120.00 & 1.49 & 117.00 & 958.00 & 4.80 & 3.80 & 1.26 & 1.39 & 0.06 & 0.21 & 17.00 & 35.90 \\
\hline & & 202.70 & 203.70 & 53.10 & 79.90 & 1.28 & 72.40 & 295.00 & 7.50 & 5.40 & 1.38 & 2.47 & 0.07 & 0.42 & 18.00 & 56.60 \\
\hline & & 209.50 & 210.50 & 107.00 & 131.00 & 1.54 & 192.20 & 1569.00 & 5.60 & 4.10 & 1.36 & 2.04 & 0.09 & 0.23 & 26.00 & 51.60 \\
\hline & & 219.00 & 220.00 & 101.00 & 146.00 & 1.48 & 125.40 & 1010.00 & 4.50 & 3.80 & 1.18 & 1.59 & 0.08 & 0.19 & 23.00 & 38.10 \\
\hline & & 225.90 & 226.90 & 156.00 & 197.00 & 2.16 & 110.00 & 869.00 & 5.10 & 4.60 & 1.10 & 1.42 & 0.10 & 0.21 & 20.00 & 46.60 \\
\hline & & 229.40 & 230.40 & 160.00 & 220.00 & 2.03 & 56.00 & 331.00 & 8.40 & 5.90 & 1.42 & 1.43 & 0.11 & 0.34 & 21.00 & 57.40 \\
\hline \multirow{6}{*}{\multicolumn{2}{|c|}{ A }} & 231.30 & 232.30 & 218.00 & 215.00 & 3.67 & 69.00 & 605.00 & 6.70 & 6.20 & 1.08 & 1.50 & 0.11 & 0.33 & 25.00 & 66.30 \\
\hline & & 257.30 & 258.30 & 400.00 & 338.00 & 3.68 & 40.60 & 314.00 & 10.30 & 9.70 & 1.06 & 1.27 & 0.16 & 0.46 & 23.00 & 66.90 \\
\hline & & 272.00 & 273.00 & 428.00 & 391.00 & 2.95 & 103.80 & 260.00 & 9.90 & 11.70 & 0.84 & 0.97 & 0.18 & 0.42 & 20.00 & 78.10 \\
\hline & & 84.50 & 85.50 & 32.40 & 43.90 & 0.93 & 96.40 & 140.00 & 6.80 & 7.10 & 0.95 & 3.21 & 0.02 & 0.34 & 18.00 & 36.30 \\
\hline & & 87.50 & 88.50 & 19.00 & 21.80 & 0.47 & 80.00 & 101.00 & 4.70 & 3.50 & 1.34 & 1.06 & 0.03 & 0.16 & 12.00 & 18.50 \\
\hline & & 89.50 & 90.50 & 51.60 & 79.10 & 1.14 & 119.20 & 297.00 & 9.50 & 8.20 & 1.16 & 1.73 & 0.03 & 0.36 & 18.00 & 47.80 \\
\hline
\end{tabular}

